\title{
Hippocampal CA1 Interneurons: An in vivo Intracellular Labeling Study
}

\author{
Attila Sik, ${ }^{a}$ Markku Penttonen, ${ }^{\mathrm{b}}$ Aarne Ylinen, ${ }^{\mathrm{c}}$ and György Buzsáki \\ Center for Molecular and Behavioral Neuroscience, Rutgers, The State University of New Jersey, Newark, New \\ Jersey 07102
}

\begin{abstract}
Fast spiking interneurons in the CA1 area of the dorsal hippocampus were recorded from and filled with biocytin in anesthetized rats. The full extent of their dendrites and axonal arborizations as well as their calcium binding protein content were examined. Based on the spatial extent of axon collaterals, local circuit cells (basket and O-LM neurons) and long-range cells (bistratified, trilaminar, and backprojection neurons) could be distinguished. Basket cells were immunoreactive for parvalbumin and their axon collaterals were confined to the pyramidal layer. A single basket cell contacted more than 1500 pyramidal neurons and 60 other parvalbumin-positive interneurons. Commissural stimulation directly discharged basket cells, followed by an early and late IPSPs, indicating interneuronal inhibition of basket cells. The dendrites of another local circuit neuron (O-LM) were confined to stratum oriens and it had a small but high-density axonal terminal field in stratum lacunosum-moleculare. The fastest firing cell of all interneurons was a calbindin-immunoreactive bistratified neuron with axonal targets in stratum oriens and radiatum. Two neurons with their cell bodies in the alveus innervated the CA3 region (backprojection cells), in addition to rich axon collaterals in the CA1 region. The trilaminar interneuron had axon collaterals in strata radiatum, oriens and pyramidale with its dendrites confined to stratum oriens. Commissural stimulation evoked an early EPSP-IPSP-late depolarizing potential sequence in this cell. All interneurons formed symmetric synapses with their targets at the electron microscopic level. These findings indicate that interneurons with distinct axonal targets have differential functions in shaping the physiological patterns of the CA1 network.
\end{abstract}

[Key words: hippocampus, interneurons, biocytin, inhi-

\footnotetext{
Received Mar. 23, 1995; revised June 9, 1995; accepted June 15, 1995.

We thank Drs. T. F. Freund, C. J. McBain, I. Mody, P. A. Schwartzkroin, P. Somogyi, I. Soltész, R. D. Traub, and X.-J. Wang for their comments on the manuscript. We also thank K. G. Baimbridge and J. J. Rogers for their gifts of antibodies. This work was supported by NIH (34994), HFSP, the Whitehal Foundation, the Finnish Academy of Sciences, and the University of Jyväskylä. A.Y. and M.P. were visiting scholars at Rutgers University, supported by the Finnish Academy of Sciences.

Correspondence should be addressed to György Buzsáki, Center for Molec ular and Behavioral Neuroscience, Rutgers University, 197 University Avenue, Newark, NJ 07102.

aPermanent address: Institute of Experimental Medicine, Hungarian Academy of Sciences, Budapest, Hungary.

'Permanent address: Department of Psychology, University of Jyvăskylă, Jyväskylä, Finland.

'Permanent address: Department of Neurology, University of Kuopio, Kuopio, Finland.

Copyright 1995 Society for Neuroscience 0270-6474/95/156651-15\$05.00/0
}

bition, axonal tree, network, parvalbumin, calbindin, calretinin, synapses, $\mathrm{GABA}_{A}, \mathrm{GABA}_{\mathrm{B}}$ ]

Although considerable knowledge has accumulated about the connectivity and major molecular and channel properties of hippocampal principal cells (Tamamaki et al., 1988; Amaral and Witter, 1989; Lopes da Silva et al., 1990; Tamamaki and Nojyo, 1990, 1991; Traub and Miles, 1991; Seeburg, 1993; Li et al., 1994), it is becoming clear that their network interactions in real brains cannot be understood without knowledge of their inhibitory interneuronal control. Traditionally, interneurons have been believed to contact neurons within a local region of the cortex, in contrast to principal cells, which send their axons to distant regions of the brain (Ramón y Cajal, 1911; Nicoll, 1994). Recent works suggest, however, that there are several groups of hippocampal inhibitory cells with different circuit, physiological and biochemical properties, and hypothesized functions (Struble et al., 1978; Alonso and Køhler, 1982; Somogyi et al., 1983, 1984; Misgeld and Frotscher, 1986; Ribak et al., 1986; Michelson and Wong, 1991; Miettinen et al., 1992; Tóth and Freund, 1992; Tóth et al., 1993; Sik et al., 1994a). Interneuronal groups may receive different local and extrinsic inputs, possess various intrinsic molecular and functional properties, and target different somatodendritic segments of the principal cells (Somogyi et al., 1983; Freund et al., 1990; Gulyás et al., 1993b; McBain and Dingledine, 1993; Miles and Poncer, 1993; Buhl et al., 1994; Miles et al., 1994; Sik et al., 1994a,b). Although interneurons numerically represent a minority in the hippocampus, they can regulate various aspects of the operational modes of principal cells through their widespread and strategically wired axon collateral systems.

To date, the variety of the anatomical classes of interneurons may be contrasted to the paucity of information about their distinctive physiological roles. Recent observations suggest that distinct classes of interneurons may be involved in the induction and maintenance of network oscillations in the hippocampus in the theta, gamma $(40-100 \mathrm{~Hz})$ and ultrafast $(200 \mathrm{~Hz})$ frequency ranges (Soltész and Deschenes, 1993; Buzsáki and Chrobak, 1995; Bragin et al., 1995; Wittington et al., 1995; Ylinen et al., $1995 a, b)$ as well as in the regulation of dendritic plasticity and fast neuronal transmission (Traub et al., 1994). Identification of the various subgroups of interneurons is a prerequisite for studying their selective, behavior-dependent control of hippocampal networks and for understanding the functional consequences of their impairment in disease. Furthermore, quantitative data on the connectivity of single neurons is an absolute prerequisite for meaningful computational models of cortical function. In this study we recorded from interneurons of the hippocampal CAl 
region of the intact brain, filled them with the tracer biocytin, and reconstructed their whole dendritic and axonal arbors, and in some cases identified their calcium binding protein contents as well as their synaptic targets.

\section{Materials and Methods}

One hundred and eighty-three Sprague-Dawley (250-350 gm) rats were anesthetized with urethane $(1.3-1.5 \mathrm{~g} / \mathrm{kg})$ and placed in a stereotaxic apparatus. Other information obtained on this animal group have been published (Li et al., 1994; Sik et al., 1994; Ylinen et al., 1995a,b). The body temperature of the rat was kept constant by a small animal thermoregulation device. The scalp was removed and a small $(1.2 \times 0.8$ $\mathrm{mm}$ ) bone window was drilled above the hippocampus (anteromedial edge at $A P=3.3$ and $L=2.2 \mathrm{~mm}$ from bregma) for extra- and intracellular recordings. The cisterna magna was opened and the cerebrospinal fluid was drained to decrease pulsation of the brain. A pair of stimulating electrodes $(100 \mu \mathrm{m}$ each, with $0.5 \mathrm{~mm}$ tip separation) was inserted into the right fimbria-fornix $(\mathrm{AP}=1.3, \mathrm{~L}=1.0, \mathrm{~V}=4.1)$ to stimulate the commissural inputs. Extracellular recording electrodes (three $20 \mu \mathrm{m}$ insulated tungsten wires) were inserted at the medial edge of the bone window. The uppermost wire was placed into the CA1 pyramidal layer and the remaining two wires aimed at the hippocampal fissure and the hilus, respectively. After the intracellular recording electrode was inserted into the brain, the bone window was covered by a mixture of paraffin and paraffin oil in order to prevent drying of the brain and decrease pulsation. The distance of the intracellular and extracellular electrodes was $0.5-1.5 \mathrm{~mm}$ in the anteroposterior and 0.0 $0.5 \mathrm{~mm}$ in the lateral directions.

Micropipettes for intracellular recordings were pulled from $2.0 \mathrm{~mm}$ diameter capillary glass. They were filled with $1 \mathrm{M}$ potassium acetate in $50 \mathrm{~mm}$ 'Iris buffer, containing also $3 \%$ biocytin for intracellular labeling. In vivo electrode impedances varied from 60 to $100 \mathrm{M} \Omega$ Once stable intracellular recordings were obtained, evoked and passive physiological properties of the cell were determined. Field activity recorded through the extracellular electrode was filtered between $1 \mathrm{~Hz}$ and $5 \mathrm{kHz}$. The intracellular signal from the amplifier (Axoclamp-2B) was digitized both as a DC signal and after further amplification $(5 \times)$ and filtering $(0.1 \mathrm{~Hz}$ to $5 \mathrm{kHz})$. The direct and amplified intracellular activity and the extracellular field/unit were digitized at $10 \mathrm{kHz}$ with 12 bit precision (ISC-16 board, RC Electronics). The data were stored on optical disks. Spontaneous membrane oscillations were examined in the frequency domain by calculating the fast Fourier transform of frequency (Buzsáki et al., 1983)

After the completion of the physiological data collection or when the membrane potential of the recorded neuron began to deteriorate at any phase of the experiment, biocytin was injected through a bridge circuit (Axoclamp-2B) using $300 \mathrm{msec}$ depolarizing pulses at $2-5 \mathrm{nA}$ at $1 \mathrm{~Hz}$ for 8 to $60 \mathrm{~min}$. Neuronal activity was followed throughout the procedure. Interneurons with incomplete penetration or shorter than $8 \mathrm{~min}$ periods of biocytin injection are not included in this study, since these short injections never resulted in complete labeling of the axonal tree of the interneurons or other cells. After 2-12 hr postinjection survival times the animals were given an urethane overdose and then perfused intracardially with $100 \mathrm{ml}$ physiological saline followed by $400 \mathrm{ml}$ of $4 \%$ paraformaldehyde, $0.1 \%$ glutaraldehyde, and $15 \%$ saturated picric acid dissolved in $0.1 \mathrm{M}$ phosphate buffer $(\mathrm{pH}=7.3$ ). The brains were then removed and stored in the fixative solution overnight. Thick (60 or $100 \mu \mathrm{m}$ ) coronal sections were cut and processed for light and electron microscopy.

Double labeling of intracellularly filled cells. A three-step procedure was used for double labeling of biocytin labeled cells to avoid nonspecific crossreaction of antibodies. Every third section was washed several times in $0.1 \mathrm{M} \mathrm{PB}$, immersed in cryoprotective solution (25\% sucrose, $10 \%$ glycerol in $0.01 \mathrm{MPB}$ ), freeze thawed in liquid nitrogen, and washed again in several changes of $0.1 \mathrm{M} \mathrm{PB}$, before incubated in $A B C$ solution ( $2 \mathrm{hr}$ to overnight). The peroxidase reaction was developed with ammonium-nickel sulfate-intensified 3,3'-diaminobenzidine (DAB$\mathrm{Ni}$ ) as a chromogene, to produce a deep blue to black end product. After microscopic examination of the already stained sections, the position of the soma and/or main dendrites could be predicted from the identified dendrites. Next, the neighboring sections were immunostained with one to three antibodies against parvalbumin, calretinin, or calbindin. Antibody selection was based on location, physiological properties, spine density, and axonal arbor of the labeled interneuron and the known distribution of chemically different subgroups of interneurons. The second antiserum was anti-rabbit IgG conjugated with fluorescein (FITC). Cell bodies and neuronal processes in the vicinity of the intracellularly labeled cell were photographed and videotaped. In case of a negative result, the section was immunoreacted against another calcium binding protein. In the last step, these sections were also developed for biocytin (DAB-Ni) and FITC-labeled videoframes were compared for possible overlap with the intracellularly filled cell. The antisera have been extensively tested for specificity by the producers: rabbit anticalbindin D28K (R202; Baimbridge and Miller, 1982), rabbit anti-parvalbumin (R301; Baimbridge and Miller, 1982), and rabbit anti-calretinin (Rogers, 1989). Additional naive rats were used to count the number of parvalbumin-immunoreactive (four rats) neurons in the different layers of the $\mathrm{CA} 1$ region. These numbers were used to calculate convergence of these cell types from the ratio of immunolabeled cells and pyramidal cells and the information obtained from the intracellularly labeled cells using the formula: $N_{\mathrm{IR}} \times D=$ total number of links $=\mathrm{N}_{\mathrm{p}}$ $\times$ C, where $N_{I R}$, number of immunoreactive cells; $N_{P}$, number of pyramidal neurons in the same volume, $D$, divergence, and $\mathrm{C}$, convergence. The absolute number of pyramidal cells in a given section was calculated by multiplying the number of parvalbumin-immunoreactive cells by the ratio of parvalbumin-immunoreative interneurons and pyramidal cells (Aika et al., 1994).

Visualization of parvalbumin-immunoreactive target interneurons. The DAB-Ni stained sections were incubated in rabbit anti-parvalbumin (1:1500) antiserum for $2 \mathrm{~d}$. The second antiserum (overnight) was antirabbit $\operatorname{IgG}(1: 50, \mathrm{ICN})$, and the third layer was rabbit peroxidase antiperoxidase complex (DAKOPATTS, 1:100, overnight). The second immunoperoxidase reaction was developed with $\mathrm{DAB}$ alone, giving a brown reaction product. During the entire $\mathrm{ABC}$ staining and immunocytochemical procedure $50 \mathrm{~mm}$ Tris-buffered saline (TBS, $\mathrm{pH} 7.4$ ) containing $1 \%$ normal goat serum was used for washing and for dilution of the antisera. For light microscopic preparations, all the solutions contained $0.5 \%$ Triton X-100 to enhance the penetration of antibodies.

Axon tracing. Sections were viewed at $40 \times$ magnification and axon collaterals were traced with the aid of a drawing tube (Sik et al., 1993). Potential contact points with immunolabeled postsynaptic cells in double-labeled sections were marked on the drawings and reexamined with oil immersion $(100 \times)$. Interbouton intervals were also measured with oil immersion in different layers. Random samples of boutons and bouton contacts with ncurons were examined with an electron microscope. The length of the axon collaterals were measured from the paper tracings with a digitizing table and the two-dimensional axon length was calculated for each coronal section. These data were then used to describe the axon length distribution in the septo-temporal axis, relative to the location of the cell body (Figs. $2 B, 5 B, 6 B$, and $7 B$ ). The axon length was divided by the average interbouton interval to calculate the total number of boutons and the number of boutons per section.

Preparation for electron microscopy. For electron microscopy, sections were treated with $1 \% \mathrm{OsO}_{4}$ for $1 \mathrm{hr}$, dehydrated in ethanol and propylene oxide, counterstained with uranil-acetate, and embedded in Durcupan. Areas innervated by biocytin-labeled axons were selected and reembedded for ultrathin sectioning. Serial ultrathin sections were cut and mounted on single-slot Formvar-coated copper grids (Sigma, St. Louis, MO). The ultrathin sections were counterstained by leadcitrate and examined by a Philips CM 10 electron microscope.

\section{Results}

Our active search for interneurons (nonpyramidal cells) was confined to the alveus/stratum oriens and stratum pyramidale of the CA1 region. In accordance with the anatomical distribution of the interneurons (Aika et al., 1994), most of the cells penetrated were pyramidal cells. Interneuron recordings were identified by their distinct physiological characteristics, including fast spontaneous activity $(10-400 \mathrm{~Hz})$, short-duration action potentials $(<$ $0.5 \mathrm{msec}$ at $50 \%$ amplitude), pronounced spike afterhyperpolarization after spontaneous action potentials and sustained high frequency firing in response to depolarizing intracellular current pulses (Schwartzkroin and Mathers, 1978; Kawaguchi and Hama, 1987a; Lacaille and Schwartzkroin 1988a,b). The input resistance of the interneurons (range: 30 to $90 \mathrm{M} \Omega$ ) was larger than in pyramidal cells recorded under the same conditions ( 20 
$\pm 3.0 \mathrm{M} \Omega$; Li et al., 1994). On the basis of histological identification, six cells were basket cells, two interneurons arborized primarily in the basal and apical dendritic layers, two neurons innervated exclusively the distal apical dendrites of pyramidal cells, and the remaining two neurons innervated cells beyond the CA1 region (backprojection interneurons).

\section{Basket cells}

Anatomical properties. Two of the six basket cells were only partially filled as evidenced by the gradual fading and disappearance of distal axon collaterals. Nevertheless, these cells fulfilled the histological criteria of basket neurons, since their axon arborization was visualized in sufficient detail to conclude that areas other than the pyramidal layer were not innervated. The somata of all basket cells were located in or close to the CA1 pyramidal layer. Dendrites were aspiny or covered with a few spines with long necks, arborized in strata oriens, radiatum and lacunosum-moleculare. In contrast to chandelier cells (Somogyi et al., 1983; Li et al., 1992), dendritic arborization of basket cells in stratum radiatum was considerably larger than in lacunosum-moleculare.

The complete axon arborizations of the basket neurons was reconstructed in the hippocampus from 19 (UR32), 29 (UR80B), 18 (M63), and 13 (M69) $60 \mu \mathrm{m}$ sections. The majority of the axon collaterals were found in stratum pyramidale with very few collaterals entering into either the stratum radiatum or stratum oriens. The total three-dimensional axon lengths for these cells were: 40,491 $\mu \mathrm{m}$ (UR32), 53,516 $\mu \mathrm{m}$ (UR80B), 48,982 $\mu \mathrm{m}$ (M63), and 41,714 $\mu \mathrm{m}$ (M69), respectively. The axonal arborization covered a circular or slightly elliptical area of the pyramidal cell layer occupying 1140 by $1154 \mu \mathrm{m}^{2}$ (UR32), 1740 by 1154 $\mu \mathrm{m}^{2}$ (UR80B), 1080 by $940 \mu \mathrm{m}^{2}$ (M63), and 780 by $920 \mu \mathrm{m}^{2}$ (M69). The septo-temporal and medio-lateral directions of axon collateral distributions, relative to the cell body, were symmetrical. On the basis of bouton density, measured in random samples at different distances from the soma (22.6 $\pm 3.9 / 100 \mu \mathrm{m}, n-50)$, the total number of bouton in these cells were 9151 (UR32), 12,095 (UR80B), 11,070 (M63), and 9427 (M69). Bouton density was independent from the distance of the axon collateral from the cell body. Since the majority of the basket cells targets are pyramidal cells and form an average of six synapses on each of their targets (Gulyás et al., 1993a; Buhl et al., 1994), we estimate that basket cells innervate between 1500 and 2000 pyramidal cells (divergence). Because in the pyramidal layer 1 out of 50 neurons are immunoreactive for parvalbumin (basket cells and chandelier cells; Aika et al., 1994) and because the divergence of chandelier cells is similar to that of the basket cells ( $\mathrm{Li}$ et al., 1992), the present findings indicate that 30 to 40 parvalbumin-immunoreactive cells converge on a single CAl pyramidal neuron.

Three basket cells were examined for the presence of parvalbumin in their somata and dendrites by double staining. Two of these were also tested for calretinin, and one of the two also for calbindin (UR32). All three cells showed immunoreactivity for parvalbumin in both the soma and dendrites (Fig. 1). Often, even axon collaterals could be clearly identified in corresponding FITC and DAB-Ni sections. None of the basket cells was immunoreactive for calretinin and calbindin.

Parvalbumin-positive targets of basket cells. In the CA1 region, parvalbumin-immunoreactive cell bodies were found in strata oriens and pyramidale, with radially running dendrites that span all layers. Axon terminals of parvalbumin-positive cells were largely restricted to the stratum pyramidale and to the bor- der between stratum oriens and stratum pyramidale. The contacts formed by the biocytin-filled and parvalbumin double-labeled basket cell (UR32) on other parvalbumin-positive targets were investigated using $100 \times$ oil-immersion objective. When contacts were identified closely to each other in neighboring sections, part of the dendritic arborization of the PV-positive target neuron was reconstructed. This was necessary in only one case; thus, the error from this source is negligible. Four light microscopically identified contacts were examined by correlated electron microscopy. In all four cases, electron microscopy revealed symmetric synapses between biocytin-filled presynaptic terminals and parvalbumin-immunoreactive postsynaptic somata (Fig. $1 C, D)$ or dendrites. Overall, 99 boutons in contact with 64 parvalbumin-immunoreactive neurons were counted (Fig. 2). Thirty-five contacts were on somata and the remaining ones on thick proximal dendrites. The majority of the targets were contacted by a single bouton, whereas 13 neurons received two to four boutons from the biocytin filled cell. For each section a ratio (probability) was obtained by dividing the number of contacted parvalbumin cells by the total number of parvalbumin-immunoreactive neurons in the area innervated by the axon collaterals. A similar calculation was made for the pyramidal cells (Fig. 2, right panel). These plots indicate that in the vicinity of the filled cell body 40 to $60 \%$ of the potential targets were contacted but this value decreased to 10 to $20 \%$ at the periphery of the innervation zone. Overall, these findings indicate that the basket cells innervale parvalbumin-immunoreactive and pyramidal cell targets with equal probability, although pyramidal cells are innervated by more boutons than basket and chandelier cells. Whether the numerically less number of boutons in target interneurons translates to smaller size IPSPS than in pyramidal cells should be determined by double recording of cell pairs.

Physiological properties. Although the general physiological properties of the interneuron cell types were similar, some notable differences were also observed. Basket cells had smaller amplitude afterhyperpolarizations $(6.5 \mathrm{mV} \pm 1.8 \mathrm{SE})$ than other interneurons (range: 11 to $17 \mathrm{mV} ; p<0.02$; Student's $t$ test). In addition, accommodation of current-induced action potentials was more pronounced in basket cells than in the other cells. Indeed, spike accommodation observed in basket cells was often comparable to that seen in CA1 pyramidal neurons.

The threshold for evoking an action potential by commissural stimulation was always lower in basket cells than in pyramidal cells recorded in the same experiment or the threshold for eliciting a population spike. At intensities suprathreshold to evoking a population spike basket cells fired two to four action potentials of decreasing amplitude, which emanated from a large depolarizing potential. The first action potential always preceded the extracellular population spike (Fig. $3 A$ ), similar to putative basket neurons recorded in extracellular studies (Buzsáki and Eidelberg, 1982). This initial burst was followed by early and late hyperpolarizing potentials associated with the cessation of firing. The duration of this suppression and the amplitude of the early (15-25 msec to peak) and late (150-250 msec to peak) IPSPs correlated with the intensity of stimulation (Fig. $3 D$ ). The amplitude of the early IPSP reached its amplitude maximum (10 $\mathrm{mV}$ ) with relatively low stimulus intensity. The late IPSP became obvious only at higher stimulation intensities but with stronger stimulation the amplitude of the late IPSP was much bigger than that of the early one (Fig. $3 D$ ). The early and late IPSPs could also be differentiated by varying the membrane potential (Fig. 3B,C). Reversal of the early IPSP occurred at 

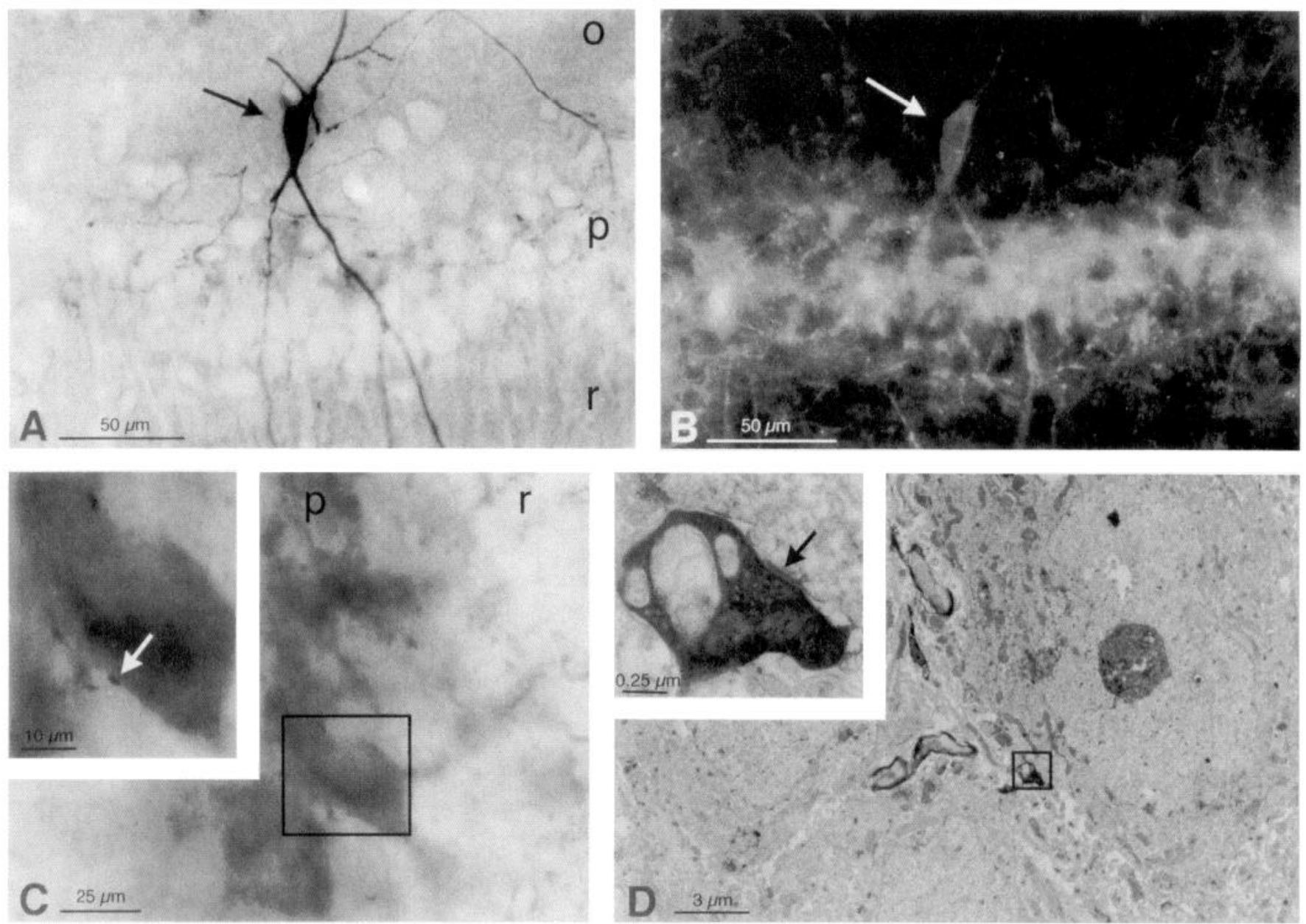

Figure 1. Basket cells are parvalbumin immunoreactive and innervate other parvalbumin-positive interneurons. $A$, Biocytin-labeled basket neuron (M69). B, Fluorescent view of parvalbumin immunoreactivity of the same section. Arrows in $A$ and $B$ point to the biocytin-filled cell body. $C$, Parvalbumin-positive target of a filled basket neuron (UR32). The white arrow in the inset $(C)$ indicates a putative synaptic contact between the biocytin-filled terminal and the cell body of a parvalbumin-immunoreactive neuron. $D$, Correlated electron microscopic analysis of the bouton indicates a symmetric synapse (arrow in inset) on the cell body. $o$, stratum oriens; $p$, CA1 pyramidal layer; $r$, stratum radiatum.

approximately $-70 \mathrm{mV}$ and of the late IPSP between $-90 \mathrm{mV}$ and $110 \mathrm{mV}$. Repetitive stimulation at $1 \mathrm{~Hz}$ or higher could attenuate both the early and especially the late IPSPs, and the late IPSP could be converted into a late depolarizing potential from which action potentials emanated (not shown). The frequency recruitment of the late discharges was similar to that described earlier in extracellular studies of putative basket cells (Andersen et al., 1963; Buzsáki and Eidelberg, 1982).

Basket cells had a relatively high level of spontaneous firing (5 to $60 \mathrm{~Hz}$ ) when rhythmic theta activity was present in the background (Fig. 4). The membrane potential displayed rhythmic modulation and bursts of two to six action potentials, phase locked to the extracellular theta waves. These fast bursts could be prevented by hyperpolarization of the neuron, and this procedure revealed a 20 to $60 \mathrm{~Hz}$ oscillation of the membrane superimposed on the slow theta oscillation. In the absence of extracellular theta EEG activity, the discharge rate of the basket cells decreased and both the fast and theta membrane oscillation diminished or disappeared (Fig. 4B,C).

Alveus/oriens interneuron with lacunosum-moleculare axon arborization $(O-L M)$

The cell bodies and dendrites of these neurons (M50; M247) were confined to the stratum oriens and alveus. The axon col- laterals of of M50 arborized and contained boutons almost exclusively in the stratum lacunosum-moleculare $(91.5 \%)$ with only few local collaterals in stratum oriens $(7 \%)$ and a few fibers entered the subiculum (1.5\%). Most collaterals projected septally from the cell body (Fig. 5A,B). Another important feature of this cell was its limited septo-temporal and medio-lateral extent of the termination field $(840 \mu \mathrm{m}$ by $500 \mu \mathrm{m})$. The total axon length of the O-LM cell was $63,436 \mu \mathrm{m}$. Based on bouton density $(26.6$ $\pm 4.0 / 100 \mu \mathrm{m})$, the calculated total number of boutons was 16,874 . Thus, even though the spatial extent of the terminal field was limited, the total number of putative synapses was higher than in the basket cells, indicating that the incidence of target innervation was similar or higher than in basket neurons. Electron microscopic examination confirmed that boutons represented synapses on spines of presumed pyramidal cells as well as on small-diameter dendritic shafts of pyramidal cells and/or interneurons (Fig. 5E,F). The axonal distribution of M247 was very similar to M50. However, very weak immunolabeling of the axon collaterals of this cell prevented reconstruction of the axonal tree.

An important physiological feature of these neurons was the large time-dependent inward rectification (sag in the response), which was visible even at small current injections (Fig. $5 C$ ), 
A

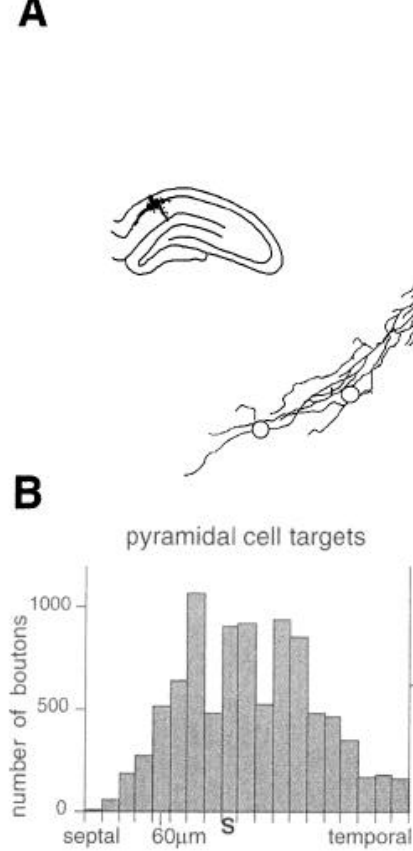

consistent with in vitro observations (McBain, 1994). Low in tensity stimulation of the commissural input evoked only short latency $(<5 \mathrm{msec})$ IPSPs. Strong stimulus intensities elicited only a single action potential and only after the occurrence of the extracellularly recorded population spikes. These observations suggest that O-LM neurons are innervated by the nearby CA1 pyramidal cells but not by commissural fibers.

Neurons with a similar confinement of their axonal trees to the stratum lacunosum-moleculare have been described in the CA3 region of the guinea pig (Gulyás et al., 1993) and the CA1 region of the rat (McBain et al., 1994). Our in vivo finding confirms that the restricted arborization of the axon collaterals of O-LM cells in vitro is not due to the slicing-induced loss of collaterals in other layers.

\section{Calbindin positive alveus/oriens interneuron with bistratified axon arborization}

In contrast to basket cells, axon collaterals of this neuron type only crossed the pyramidal layer and most of its axon collaterals arborized and terminated in strata oriens and radiatum. The cell body of the interneuron (M83) was located in stratum oriens and possessed both radially and horizontally oriented dendrites. The "apical" dendrites protruded into the stratum radiatum but did not enter stratum lacunosum-moleculare (Fig. 6A). The dendrite surfaces were smooth. Earlier in vitro studies termed this class of cells bistratified interneuron (Buhl et al., 1994). The section containing the cell body was immunoreacted against the calcium binding protein calbindin and proved calbindin positive (Fig. 6D).

The principal axon arose from the cell body and ascended through stratum pyramidale into the stratum radiatum and descended into the stratum oriens and formed dense terminal clouds in both layers. The entire axon tree was reconstructed from $31(60 \mu \mathrm{m})$ consecutive sections. The axon collaterals innervated the entire mediolateral (CA3-subiculum) extent of the CA1 region with most collaterals terminating in the stratum oriens (53\% of total length) and stratum radiatum (39\%). Some
Figure 2. Neuronal targets of an intracellularly labeled basket cell (UR32). $A$, Reconstructed dendritic tree and axon arborization from seven neighboring sections (out of 19 sections containing axon collaterals). Large circles indicate contacts with other parvalbumin interneurons. Inset: position of the neuron in the coronal plane. In this and in subsequent figures the septotemporal level of coronal drawings correspond to the position of the soma. $B$, Distribution of pyramidal cell and parvalbumin-positive cell $(P V)$ targets of the intracellularly labeled basket cell in the septotemporal direction (orthogonal to the plane in A). Left ordinate of the pyramidal cell graph indicates number of boutons per $60 \mu \mathrm{m}$ section. Right panel: probability of pyramidal (pyr) and parvalbumin-immunoreactive $(P V)$ neurons innervated by the filled cell. For each section a ratio (probability) was obtained by dividing the number of contacted parvalbumin (or pyramidal) cells by the total number of parvalbuminimmunoreactive (or pyramidal) neurons in the area innervated by the axon collaterals. $S$, position of the soma. caudally projecting collaterals reached and terminated in subicular region $(3.5 \%)$. Few axon collaterals crossed the pyramidal layer $(4.7 \%)$, but the layer was practically devoid of terminal boutons. As shown in Figure $6 B$, the axon terminal cloud was asymmetric, with most of the axon collaterals projecting caudal to the cell body. The area occupied by the axon collaterals was $1860 \mu \mathrm{m}$ (septo-temporal) by $2090 \mu \mathrm{m}$ (medio-lateral). The total axon length was $78,800 \mu \mathrm{m}$ with 16,600 boutons (bouton density $21 \pm 5.6 / 100 \mu \mathrm{m} ; n=100)$. Since a single bistratified cell contacts pyramidal targets by six synapses (Buhl et al., 1994), our findings indicate that an individual neuron may innervate as many as 2500 pyramidal cells (divergence).

Of all cells in these experiments, this neuron maintained the highest firing frequency $(>300 \mathrm{~Hz})$ upon current injection (1 $\mathrm{nA}$ ) into the soma and displayed some spike frequency accommodation (Fig. $6 \mathrm{C}$ ). Since stimulation electrodes were not implanted in this rat, evoked properties of the cell could not be studied. However, previous work indicates that bistratified cells are strongly activated by the commissural/Schaffer collateral inputs (Buhl et al., 1994).

\section{Trilaminar interneuron}

The cell body was located in the stratum oriens/alveolar border of the septal third of the hippocampus (Fig. 7A). The soma was tested for calbindin immunoreactivity and proved negative. The dendritic arborization occupied a large area of stratum oriens, running parallel with the stratum pyramidale. The dendrites exhibited only a few dendritic spines. The main axon emerged from the soma and bifurcated, giving rise to collaterals in strata oriens, radiatum, and pyramidale. One secondary axon became myelinated in the fimbria and could not be traced further. Another main collateral traveled toward the septal pole of hippocampus, turned back to give rise to a large number of collaterals close to the level of the cell body. The axon terminals richly innervated the stratum radiatum $(68.4 \%)$, less axons were found in stratum oriens $(12.8 \%)$ and pyramidale $(16.7 \%)$. The axon collaterals were not simply crossing the pyramidal layer, as ev- 


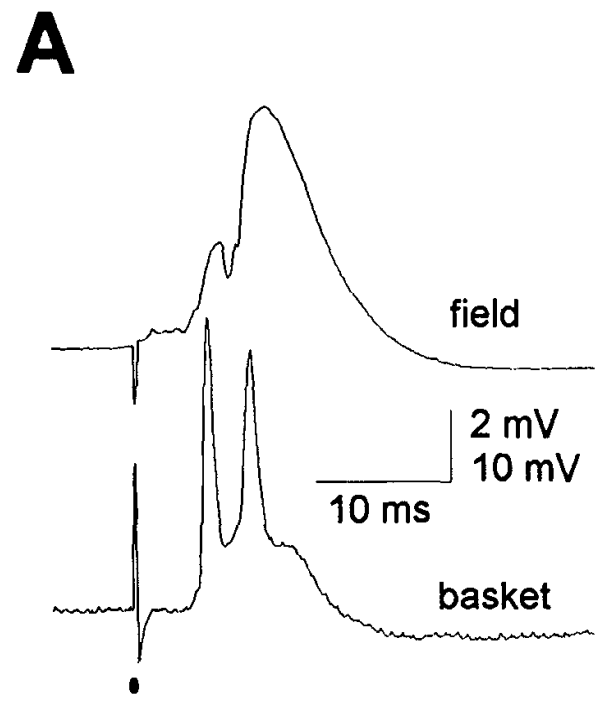

D
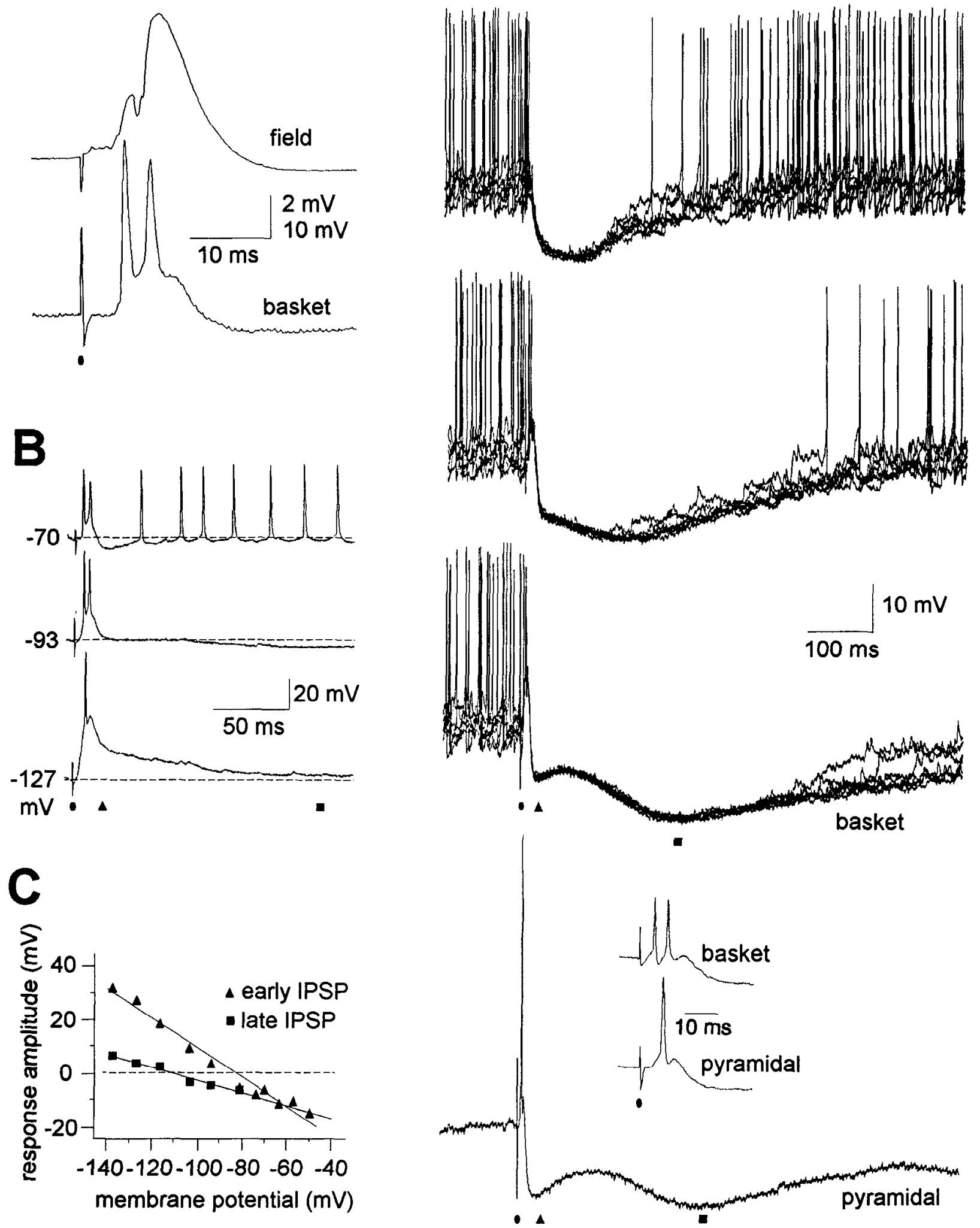

Figure 3. Evoked response properties of identified basket cells. A, Simultaneous recording of extracellular activity in the CA1 pyramidal layer ( field) and intracellular response (basket) to stimulation of the commissural path (dot). Note that the basket cell (UR80B) began to fire prior to the population spike in the field. $B$ and $C$, Voltage dependence and reversal potentials of IPSPs. $B$, Responses at RMP and two hyperpolarization levels. Triangle and square indicate early and late IPSPs, respectively. $C$, Response amplitudes as a function of the membrane potential. $D$, Six superimposed responses to increasing stimulation intensitics of the commissural input (40,60, and $100 \mu \mathrm{A})$ in another basket cell (M63). Note long-lasting cessation of spontaneous firing. Bottom: response of a pyramidal cell to $100 \mu \mathrm{A}$ stimulation. Note similar latencies of the early (triangle) and late 
A

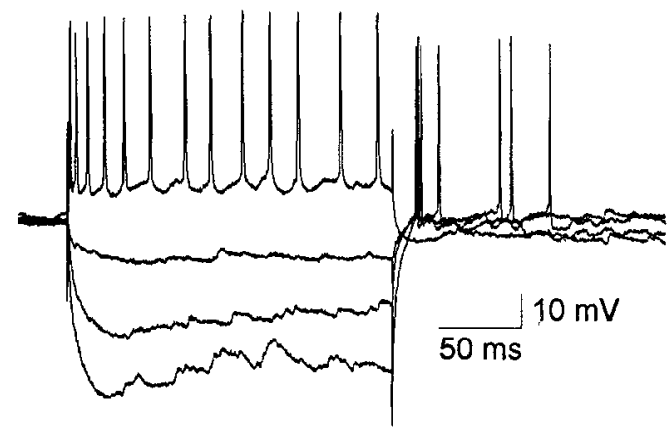

B

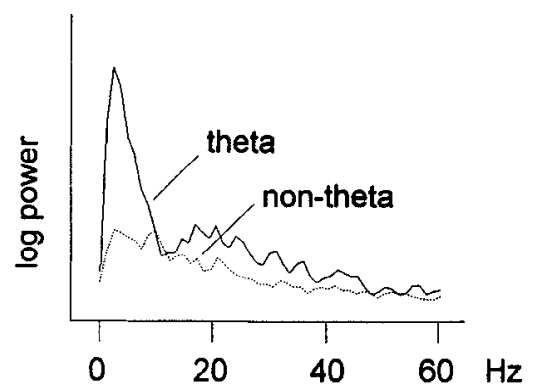

C

theta

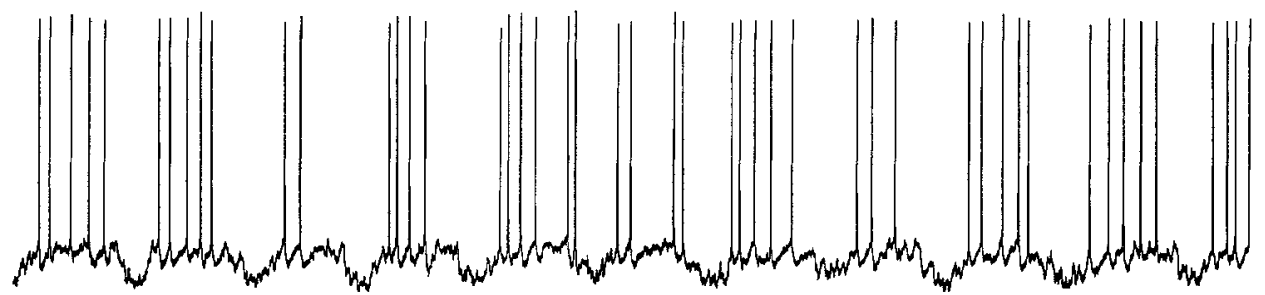

basket

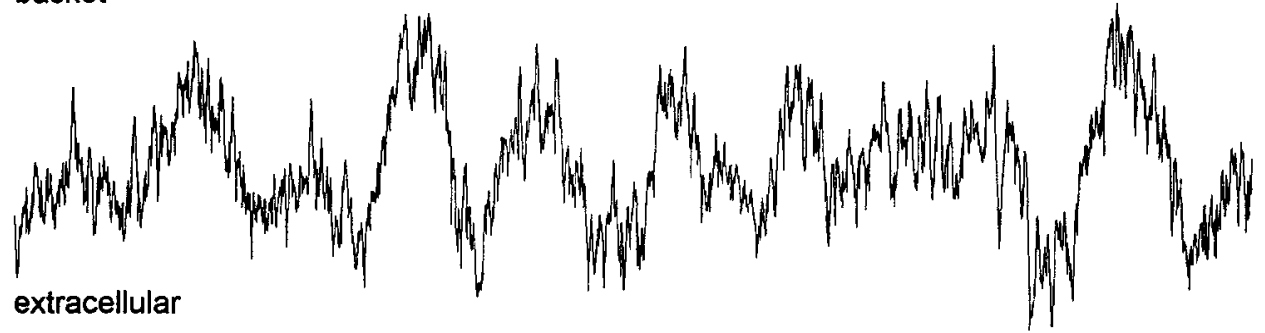

non-theta

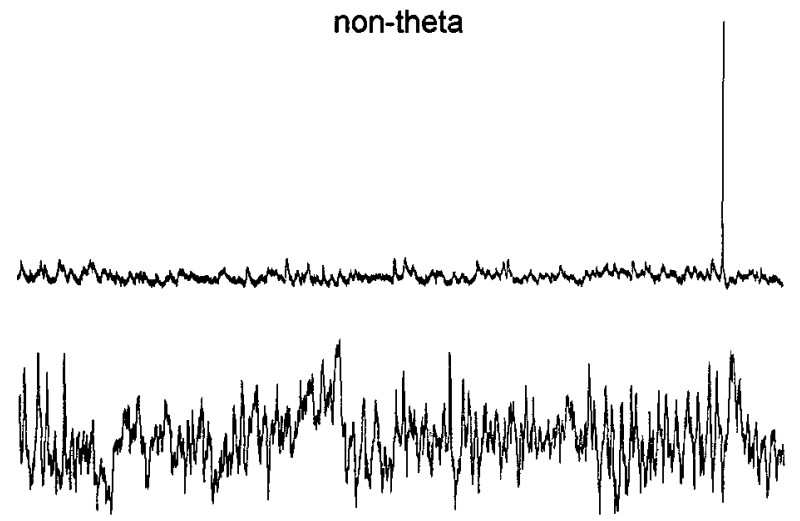

Figure 4. Intracellular theta activity in a CA1 basket cell (UR80B). A, Responses of the neuron to depolarizing $(0.4 \mathrm{nA})$ and hyperpolarizing $(-0.2$, -0.4 , and $-0.8 \mathrm{nA}$ ) current steps. $B$, Power spectrum of intraccllular membrane fluctuation in the presence and absence of extracellular theta. Action potentials were digitally removed for the calculation of power. $C$, Simultaneous recording of intracellular activity of the basket neuron and extracellular activity in the CA1 pyramidal layer during theta activity (theta, above) and its absence (non-theta, below). Note rhythmic firing of the basket cell during theta. No current was applied to the interneuron. idenced by both "en passant" and terminal boutons (Fig. 8C). A few caudally coursing collaterals entered the subiculum $(2.1 \%)$. Since the area ratio between strata radiatum, pyramidale, and oriens is about 5:1:2 in CAl region of the hippocampus (Aika et al., 1994), the findings suggest that this neuronal type can contact their targets in the pyramidal layer with a higher probability than in stratum oriens. The area occupied by the axon collaterals was $2600 \mu \mathrm{m}$ (septo-temporal) by $2450 \mu \mathrm{m}$ (mediolateral). The total axon length was $55,913 \mu \mathrm{m}$. Based on bouton density $(28.2 \pm 4.9 / 100 \mu \mathrm{m} ; n=50)$, the calculated total number of boutons was 15,767 .

Of all interneurons, this cell (M96) had the lowest threshold to commissural stimulation. It displayed long bursts of spontaneous action potentials (Fig. 8A) and large EPSPs (Fig. 8A,G). 


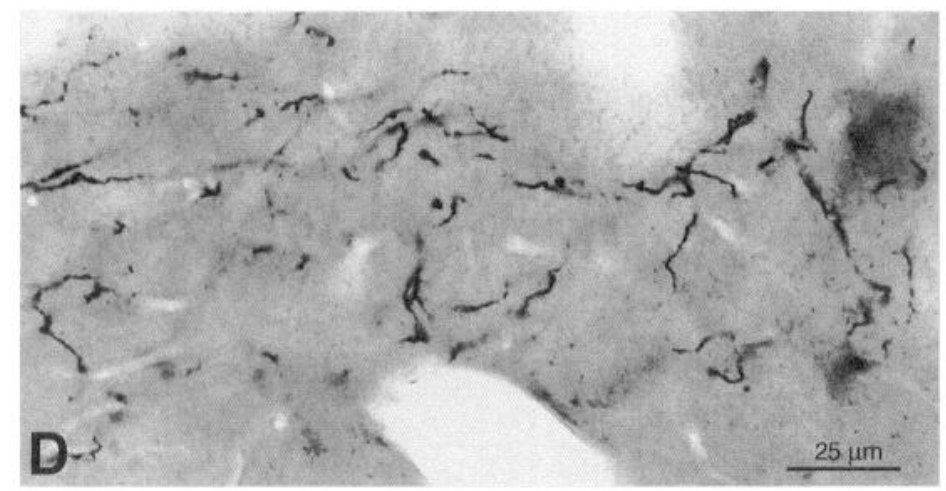

A

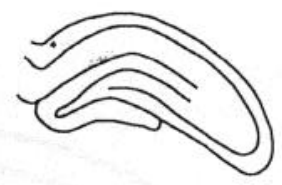

O
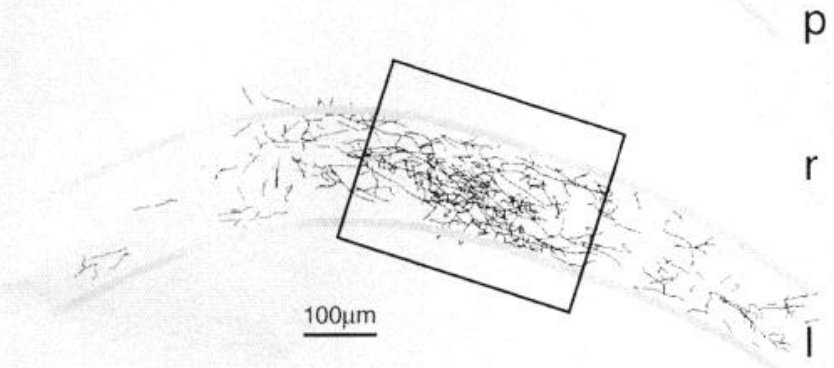
I
B
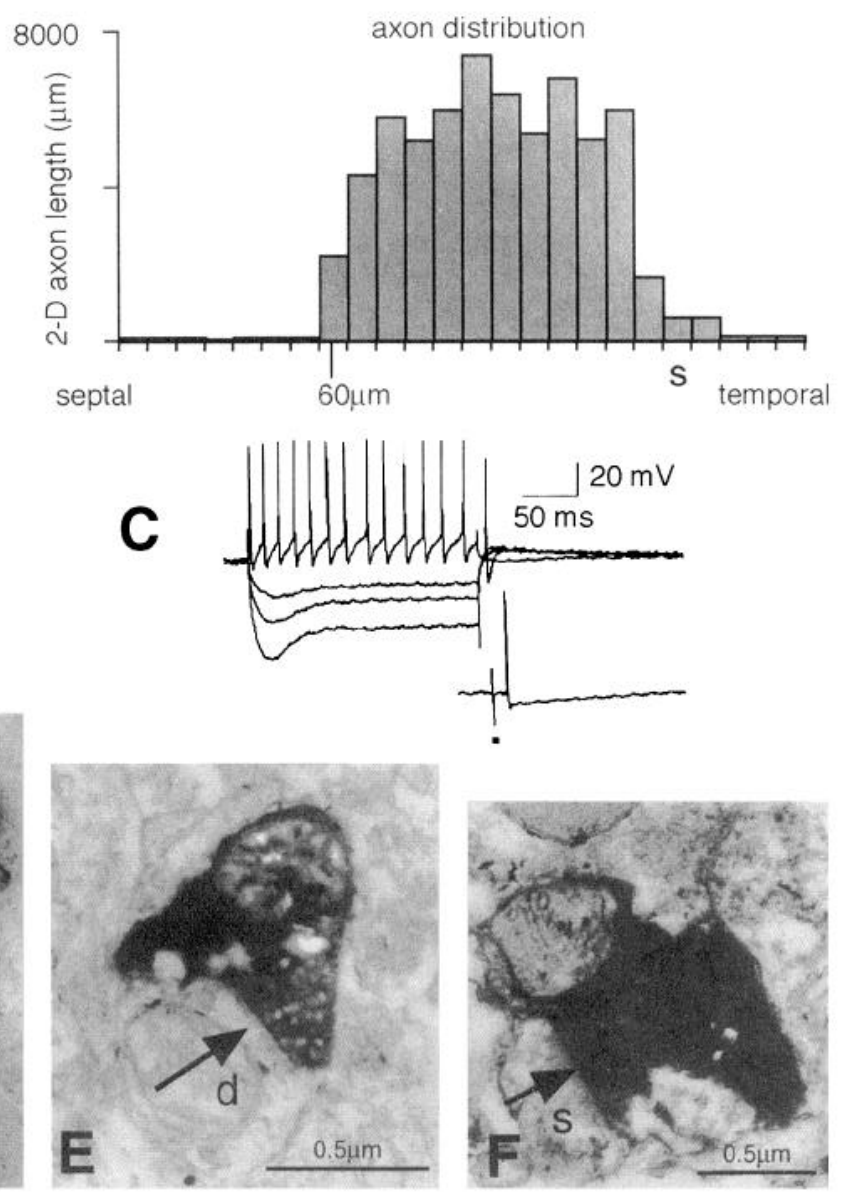

Figure 5. Stratum oriens interneuron (M50) with lacunosum-moleculare termination field (O-LM cell). A, Camera lucida reconstruction from only three consecutive $60 \mu \mathrm{m}$ sections. Black dot indicates the soma location. B. Septotemporal distribution of axon collaterals in consecutive $60 \mu \mathrm{m}$ sections. The axon tree did not exceed $800 \mu \mathrm{m}$ in diameter in either the mediolateral or septotemporal directions. $C$, Responses of the neuron to depolarizing $(0.4 \mathrm{nA})$ and hyperpolarizing $(-0.4,-0.8$, and $-1.2 \mathrm{nA})$ current steps. Note the large time-dependent inward rectification (sag in the response), visible even at small current injections. Inset: Strong commissural stimulation (black square) elicited a single spike at long latency ( 9 $\mathrm{msec}$ ). $D$, Light microscopic picture of the dense terminal field in stratum lacunosum-moleculare (boxed area in $A$ ). $E$ and $F$, At the electron microscopic level boutons terminated (arrows) on small diameter dendrites $(d)$ as well as on spines $(s)(E)$.

By increasing stimulus intensity, the neuron responded with a burst of action potentials with decreasing amplitude spikes and short interspike intervals $(>300 \mathrm{~Hz})$, emanating from a large depolarizing potential. The burst was followed by an IPSP, which in turn, was followed by a late depolarizing potential and associated burst of lower frequency action potentials (100-200 $\mathrm{Hz}$; Fig. $8 B$ ). With current-injected membrane hyperpolarization the IPSP became null at approximately $-70 \mathrm{mV}$ (Fig. $8 C$ ), whereas both the early EPSP and the late depolarizing potential increased. Further hyperpolarization of the membrane resulted in further increase of the amplitude of the early EPSP and the late depolarizing potential but with decreasing number of action potentials (Fig. 7B). At the same time, the amplitude of the IPSP, which now became depolarizing, continued to increase. The reversal potential of the IPSP suggested that it was mediated by $\mathrm{GABA}_{\mathrm{A}}$ receptors. Unidentified neurons with similar location and late depolarizing response were observed in the CA1 region in vitro (Lacaille, 1991).

The initial burst response could be elicited with low intensity $(<25 \mu \mathrm{A})$ stimulation, which in most other neurons was subthreshold for evoking an action potential. The stimulation-in- duced depolarization threshold for the burst response was approximately $-60 \mathrm{mV}$. However, when this or more positive membrane potential was achieved by injection of an intracellular current (Fig. $8 F$ ) or occurred spontaneously (Fig. $8 A$ ), only single fast spikes were observed. Even when repetitive activity occurred together with a fast membrane oscillation, the successive spikes were of similar amplitude. Such local depolarization of the dendrite presumably could not be achieved by intrasomatic current injection. In this rat, no extracellular electrode was implanted. However, when the strength of commissural stimulation was increased to a level sufficient to discharge a subsequently recorded pyramidal cell or to evoke population spikes in other experiments $(>100 \mu \mathrm{A})$, commissural activation evoked a large and long-lasting depolarization, as if the early EPSP and the late depolarizing potential merged and obliterated the intervening early IPSP (Fig. $8 D$ ). After the initial burst, the large depolarization plateau blocked the occurrence of $\mathrm{Na}^{+}$spikes and the membrane showed a small amplitude but fast $(400-500 \mathrm{~Hz})$ oscillation until the spikes recovered. These observations suggest that synaptic activation perhaps induced a dendritic spike, which in turn, triggered fast inactivating $\mathrm{Na}^{+}$spikes (Llinás, 1988). The 

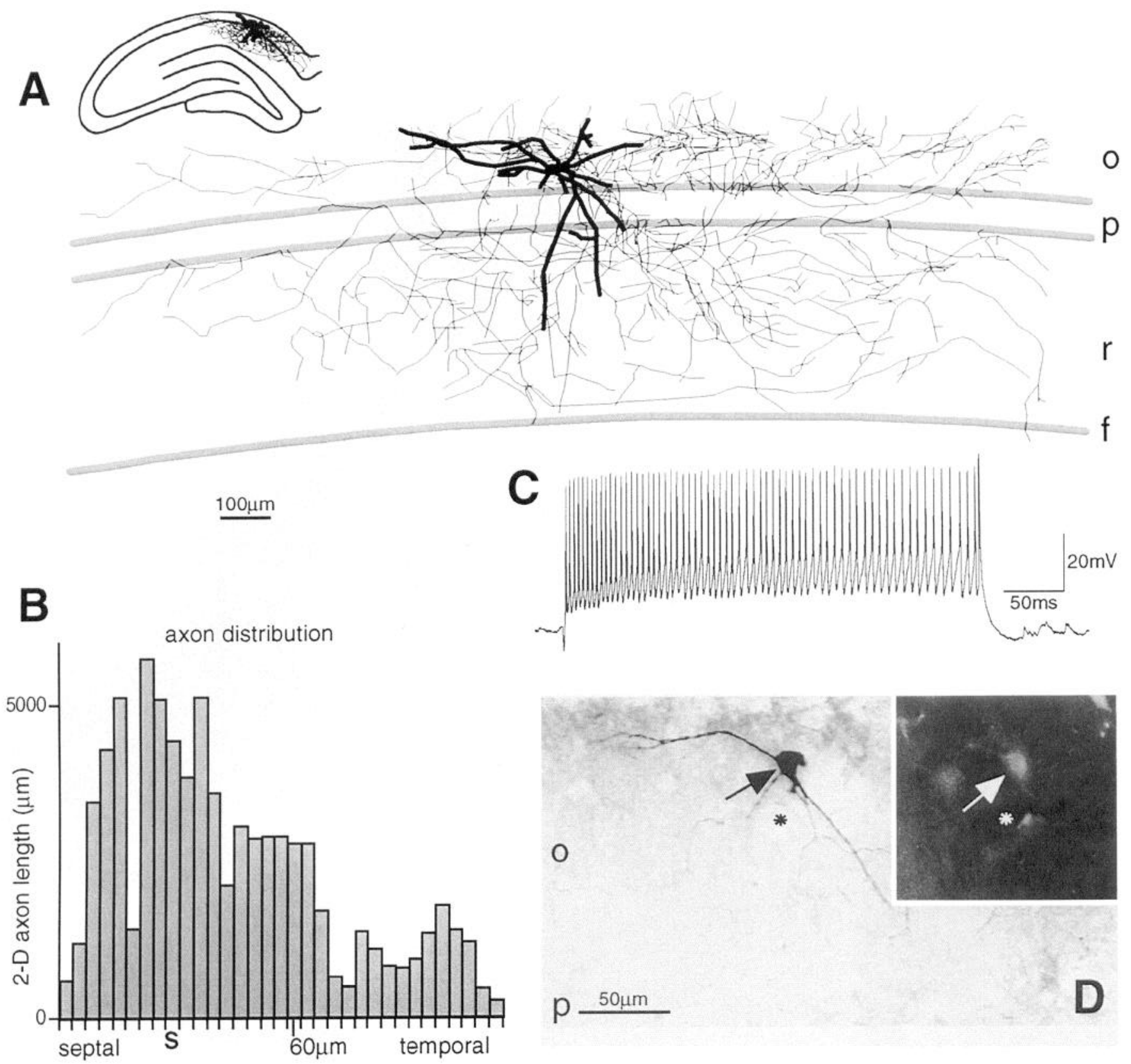

Figure 6. Bistratified calbindin-positive cell. A, Reconstruction of the entire axon collateral system (thin lines) and dendritic arborization. Axon collaterals from all coronal sections $(n=33)$ were collapsed into one. $o$, stratum oriens; $p$, CA1 pyramidal layer; $r$, stratum radiatum; $f$, hippocampal fissure. $B$, Septotemporal distribution of the axon collaterals in successive $60 \mu \mathrm{m}$ sections (orthogonal to the plane in $A$ ). $S$, position of the soma. $C$, Fast firing of the interneuron in response to intracellular current injection $(1 \mathrm{nA}) . D$, Photograph of the biocytin-labeled cell body (arrow) and main dendrites. Inset: Calbindin-immunoreactivity in the same section (FITC). White arrow indicates the immunoreactive soma of the intracellularly filled neuron. Asterisks: blood vessel.

neuron could be antidromically activated by stimulation of the contralateral fimbria-fornix at $4.1 \mathrm{msec}$ latency, indicating 1.0 to $1.5 \mathrm{~m} / \mathrm{sec}$ spike propagation in the myelinated commissural axon collateral (Fig. 8E).

In summary, both the physiological and anatomical features of this neuron were distinct from basket cells. It was also different from the bistratified interneurons of the CA1 region (Buhl et al., 1994), since its dendrites were confined to the stratum oriens, most of its collaterals terminated in strata radiatum and pyramidale, and the neuron was immunonegative for calbindin. It showed some similarity to the stratum radiatum nonpyramidal cells (SR) described in the CA3 region of the guinea pig (Gulyás et al., 1993), although the dendrites of that cell type were confined to the strata radiatum, lucidum, and pyramidale.

\section{Backprojection cells}

Axon collaterals of two cells (UR37 and M113) left the CA1 region and innervated the $\mathrm{CA} 3$ field, and one of them also the hilar region. The position and dendritic arborization of the two neurons were similar. The first cell had a total of $101,342 \mu \mathrm{m}$ long axon collaterals in the $\mathrm{CA} 1, \mathrm{CA} 3$, and the hilar region. The anatomical and physiological details of this neuron have been 

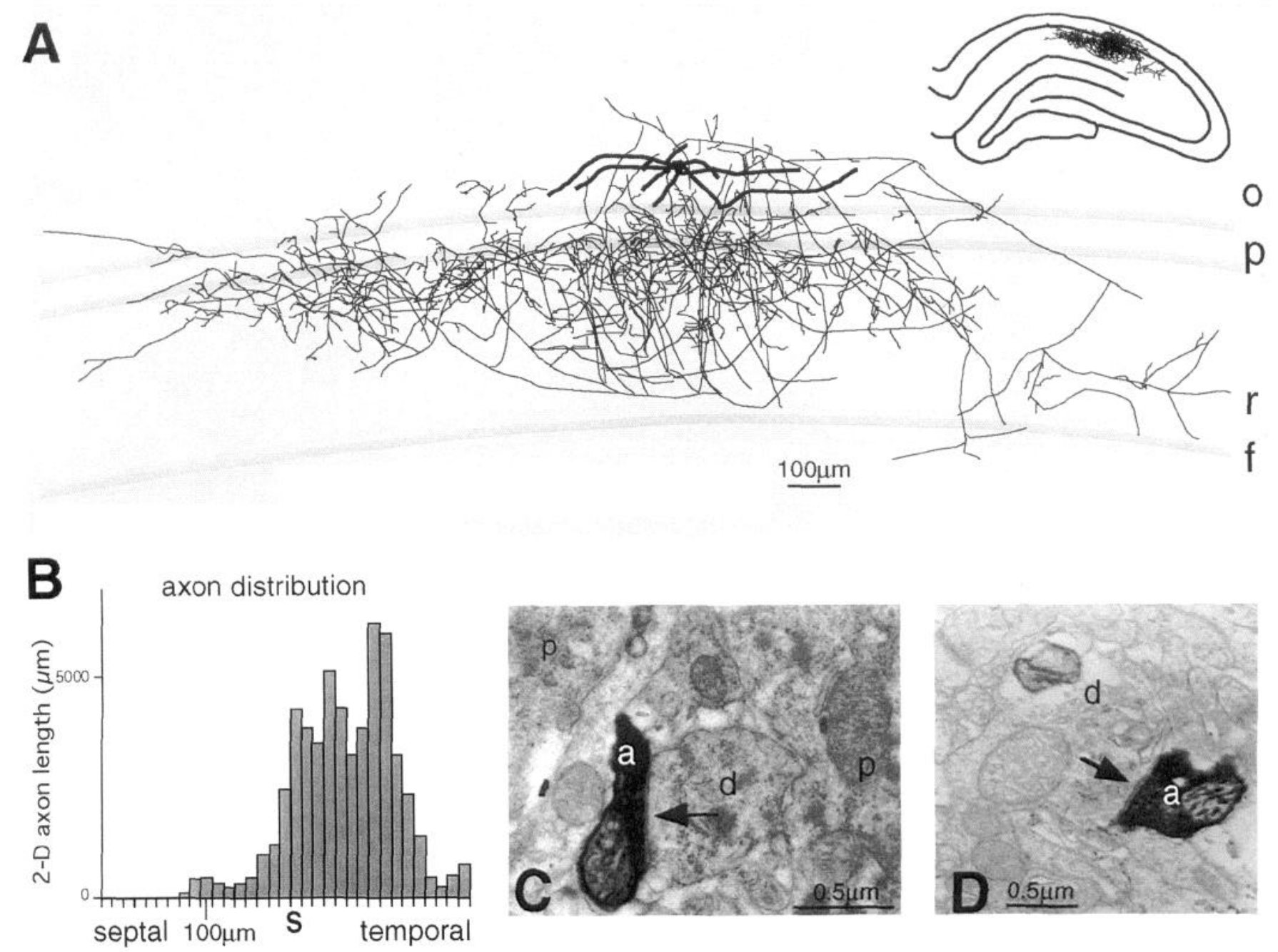

Figure 7. Trilaminar interneuron (M96). A, Reconstruction of the axon collaterals and dendrites of the interneuron. Axon collaterals from all sections were collapsed into a two-dimensional display. $o$, stratum oriens; $p$, CA1 pyramidal layer; $r$, stratum radiatum; $f$, hippocampal fissure. Some collaterals falsely appear in the stratum lacunosum-moleculare because of the two-dimensional projection of curving layer boundaries. $B$, Septotemporal distribution of the axon collaterals in successive $100 \mu \mathrm{m}$ sections. $S$, soma. $C$ and $D$, Biocytin-labeled boutons $(a)$ form symmetric synapse (arrow) on dendrites $(d)$ in the pyramidal layer $(C)$ and the stratum oriens $(D), p$ in $C$ indicates pyramidal cell bodies.

published earlier (Sik et al., 1994). The cell body of M113 was at the border of the alveus and stratum oriens and its long dendrites were confined to the stratum oriens. Reconstructed twodimensional display of the axon arbor of the second cell is shown in Figure 9. The total length of collaterals was 20,642 $\mu \mathrm{m}, 59.4 \%$ of which was in the CA1 region and $40.6 \%$ coursed back to CA3 a-b area innervating the strata oriens and radiatum. Several boutons were found in the immediate proximity of capillaries. Under the electron microscope these proved to be regular synapses, but they were separated from the capillary endothelium by only the lamina basalis and a thin process of a capillary pericyte (Fig. 9D).

After the completion of the intracellular injection, the pipette was withdrawn from the cell and a CA1 pyramidal neuron was also penetrated and filled, approximately $150 \mu \mathrm{m}$ from the interneuron. The axon collaterals of the pyramidal cell and the backprojection interneuron could be clearly separated. Axon collaterals of the interneuron did not have any bouton contacts with the pyramidal cell. On the other hand, a recurrent collateral of the pyramidal cell terminated with a bouton on the dendrite of the interneuron, suggesting that the pyramidal cell have formed only a single synapse on its interneuron target (Fig. 9D).

\section{Discussion}

Recent in vitro intracellular labeling studies revealed three main classes of inhibitory cells in the hippocampal CAl region: basket cells, chandelier cells, and bistratified cells (Buhl et al., 1994). The present findings confirmed these observations and extended them in three important ways. First, additional interneuronal types were visualized. Second, the axonal trees of our cells were completely filled, allowing us to quantitatively assess their divergence and convergence. Third, the calcium binding protein content of the interneurons was revealed in some cases. Fourth, physiological properties of the interneurons were contrasted to their anatomical features.

\section{Interneuronal types in the CAI region}

Interneurons in the hippocampus have been classified according to their calcium binding protein and peptide content (Somogyi et al., 1984; Sloviter and Nilaver, 1987; Kosaka et al., 1988; 


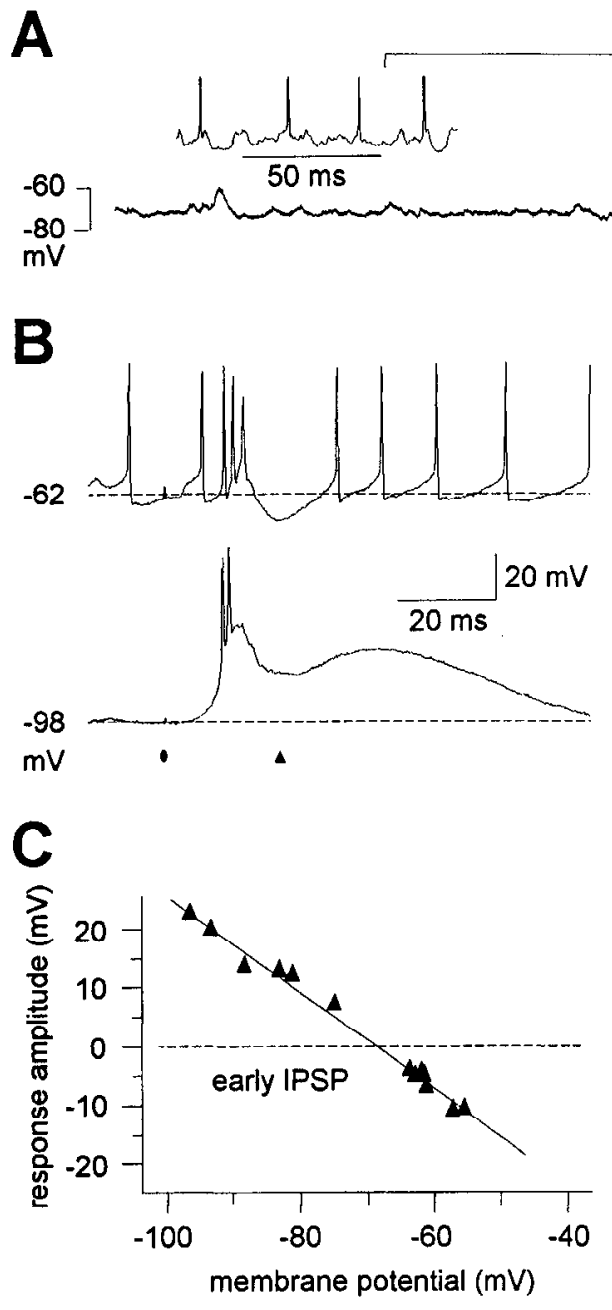

Sloviter, 1989; Gulyás et al., 1991, 1992; Miettinen et al., 1992; Tóth and Freund, 1992), inputs (Schwarzkroin and Mathers, 1978; Alger and Nicoll, 1982; Buzsáki and Eidelberg, 1982; Buzsáki 1984; Freund et al., 1990), location of their somadendritic trees (Kunkel et al., 1987; Lacaille et al., 1987; Lacaille and Schwartzkroin, 1988a,b; Scharfman et al., 1990; Lacaille, 1991; Gulyás et al., 1993a,b), glutamate receptor properties (Baude et al., 1993; McBain and Dingledine, 1993; McBain et al., 1994), and firing properties (Kawaguchi and Hama 1987a,b; Lacaille and Schwartzkroin, 1988a,b; Fraser and MacVicar, 1991). Recent intracellular labeling studies began to classify interneurons in terms of their target domains on the somatodendritic surface of principal cells (Gulyás et al., 1993a,b; Hahn et al., 1993; Halasy and Somogyi, 1993; Buhl et al., 1994; Buckmaster and Schwartzkroin, 1995), a distinction most pertinent to their physiological role.

In addition to chandelier cells, basket cells, and bistratified cells (Finch et al., 1983; Li et al., 1992; Buhl et al., 1994), we found three additional inhibitory cell types in the CA1 region. The O-LM cell terminated most prominently in the stratum lacunosum-moleculare and to some extent in stratum oriens, with rather limited septotemporal and mediolateral extent. A similar cell type has recently been described in the CA3 (Gulyás et al., 1993b) and CA1 (McBain et al., 1994) regions in vitro. O-LM neurons likely belong to the somatostatin-immunoreactive class because of the similarity of its somadendritic location to that of
Figure 8. Physiological properties of a trilaminar interneuron. $A$, Spontaneous activity. Note long train of action potentials $(60$ to $100 \mathrm{~Hz})$ and surrounding silence. Action potentials were clipped. Inset reveals fast membrane oscillation. $B$, Burst responses to commissural stimulation $(40 \mu \mathrm{A} ; d o t)$ at two different membrane potential levels. The early EPSP and action potential burst was followed by an early IPSP (triangle) and a late EPSP. $C$, Response amplitudes of the IPSP (triangle in $B$ ) as a function of the membrane potential. The linear regression line intercepts the reversal potential line (dotted) at approximately $-70 \mathrm{mV}$. $D$, Evoked responses to stronger $(100 \mu \mathrm{A})$ commissural stimulation (dot) at resting membrane potential. Note depolarization block of action potentials and fast membrane oscillation. $E$, Antidromic activation of the cell by commissural stimulation $(30 \mu \mathrm{A}: d o t)$. Three superimposed responses. The cell was slightly depolarized $(-60$ $\mathrm{mV}$ ). Note that the early (antidromic) spike occurs without a depolarizing potential, followed by an early EPSP and burst firing. $F$, Responses of the neuron to depolarizing $(0.4 \mathrm{nA})$ and hyperpolarizing $(-0.4,-0.8$, and $-1.2 \mathrm{nA})$ current steps. Arrows indicate large spontaneous EPSPs. the somatostatin neurons and because of the presence of somatostatin-immunoreactive axons in the stratum lacunosum-moleculare (Sloviter and Nilaver, 1987; Kosaka et al., 1988). The trilaminar cell is considered to be a new cell type not only because of its distinct innervation of the somata, basal, and proximal apical dendrites of pyramidal cells, but because its physiological fcatures and dendritic arbor were characteristically different from other types. Backprojection neurons are also treated as a new subgroup because they exert their inhibitory effect almost equally on CA1 and CA3 pyramidal cells. Backprojection neurons may contain the enzyme nitric oxide synthase, because axons of some neurons producing nitric oxide in stratum oriens course back from the CA1 to the CA3 and hilar regions (Sik et al., 1994a). Dircet evidence, i.e., demonstration of nitric oxide synthase in backprojection neurons, is still lacking, however. The precise chemical content of the other interneuronal subclasses has yet to be determined and it is of special importance to reveal how the distinct chemical nature of these subclasses contribute to their function. Although the above six inhibitory neuronal groups in the stratum oriens and pyramidal layer are sufficient to differentially affect the orderly arranged excitatory afferents to the CA1 region, it is expected that further research will add to this list.

Local circuit and long-range inhibition in the CAl region

On the basis of the spatial extent of axon collaterals, two major groups could be distinguished: local circuit and long-range in- 

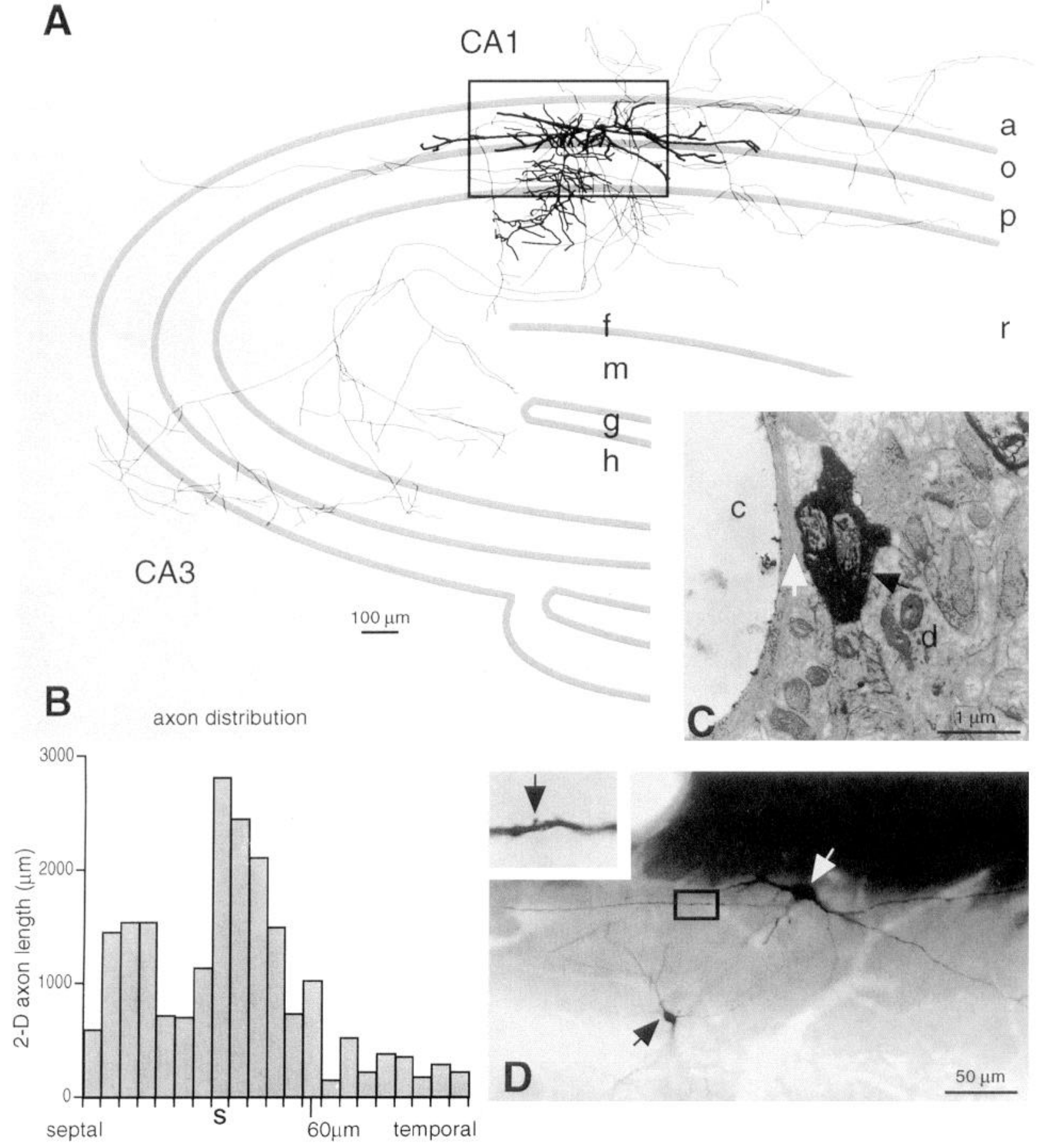

Figure 9. Backprojection interneuron (M113). A, Reconstructed two-dimensional display of the axon tree of the interneuron and dendrites of both interneuron and a labeled pyramidal cell. $o$, stratum oriens; $p$, CA1 pyramidal layer; $r$, stratum radiatum; $f$, hippocampal fissure; $m$, molecular layer; $g$, granule cell layer; $h$, hilus. $B$, Axon collateral distribution in the septotemporal axis $(60 \mu \mathrm{m}$ sections). $C$, Electron microscopic picture of a bouton in the vicinity of a capillary $(c)$ in the CA3 stratum oriens. The bouton is separated from the lamina basalis of the capillary by a thin process of a pericyte (white arrow). A symmetric synapse on dendrite is indicated by the black arrow. $D$, Light microscopic photo image of the boxed area from the reconstruction $(A)$. White arrow shows the interneuron soma in stratum oriens. A filled pyramidal cell close to the interneuron is also visible (arrow). The inset shows enlargement of the boxed area. The arrow indicates a putative synaptic contact on the interneuron dendrite from an axon collateral of the labeled CA1 pyramidal cell.

terneurons. The local circuit group contains basket cells, chandelier cells and O-LM cells, with cylindrical axon trees of less than a millimeter in diameter. A single basket cell innervated more than 1500 pyramidal neurons and 60 other parvalbuminimmunoreactive (basket and chandelier) cells. Chandelier cells in the CA1 region establish 2 to 10 release sites on the axon initial segment of a single postsynaptic neuron and also innervate more than 1000 pyramidal cells ( $\mathrm{Li}$ et al., 1992). The spatial extent of the O-LM cell was smaller than that of the basket neurons but with a higher density of axon collaterals. In this 

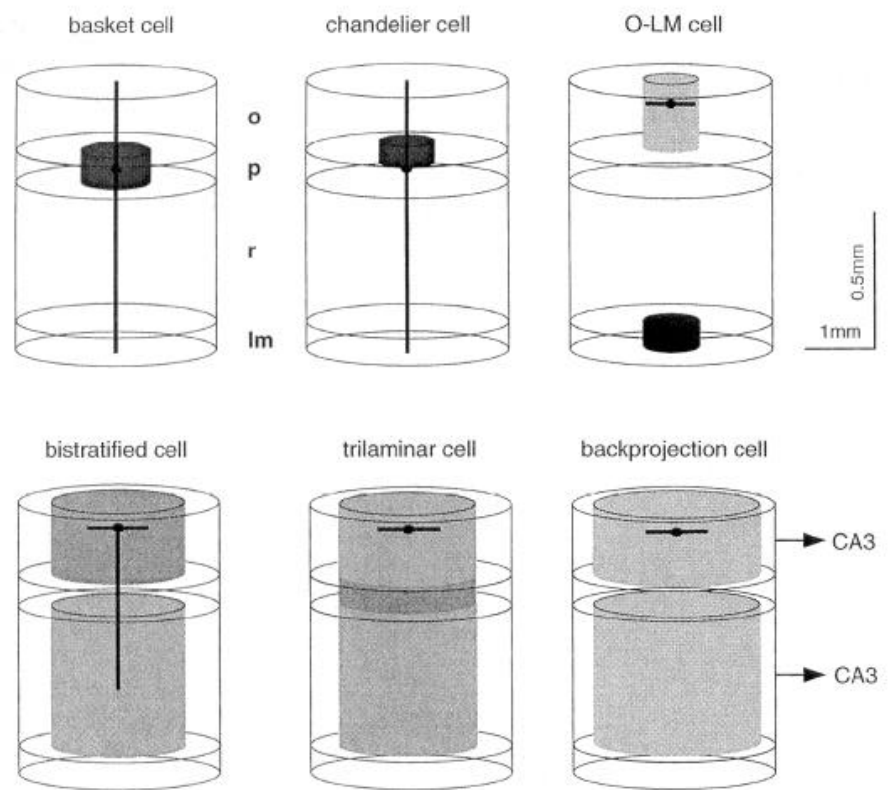
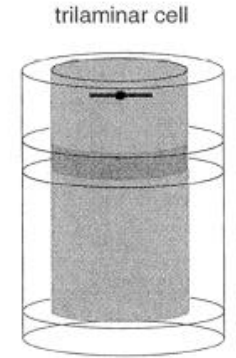

backprojection cell

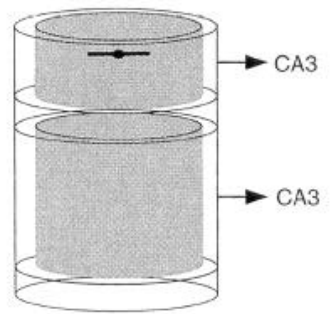

Figure 10. Three-dimensional distribution of the axonal trees of CA1 interneurons in alveus, strata oriens, and pyramidale. The intensity of gray is proportional to the axon collateral density. Upper row: local circuit cells. Bottom row: long-range interneurons. For the local circuit interneurons, the axon arbor was almost cylindrical. Axon collaterals of the long-range cells were more extensive in the septotemporal direction than in the medio-lateral (subiculo-fimbrial) direction. Data for the chandelier cell are from $\mathrm{Li}$ et al. (1992). Soma location and approximate denritic extent are also shown. Note different calibration in the y and $\mathrm{x}-\mathrm{z}$ direction. $o$, stratum oriens; $p, \mathrm{CAl}$ pyramidal layer; $r$, stratum radiatum; $l m$, stratum lacunosum-moleculare.

context, it is important to emphasize that the entorhinal cortexCA1 projection is similarly circumscribed (Tamamaki and Nojyo, 1995); thus, inhibition of an O-LM cell by its afferents may allow activation of a selected group of CA1 pyramidal cells by the entorhinal input.

The long-range interneuronal group includes bistratified cells, trilaminar, and backprojection interneurons. Long-range interneurons arborized in a much larger volume than local circuit cells. The remarkably similar bouton density of all interneurons (21-28/100 $\mu \mathrm{m})$, and the overlapping ranges of the total axonal lengths in the two groups (20 to $100 \mathrm{~mm}$ ) suggest that although the volume and the number of neurons innervated by the longrange interneurons is larger, the density of innervated postsynaptic targets is less than for the local circuit group. Long-range interneurons therefore may exert a weaker but more global effect on their targets than local circuit interneurons.

\section{Functional implications}

Despite of the small number of cells in each group, clear distinquishing physiological properties of these classes have emerged. Basket cells had significantly lower afterhyperpolarizations than that of any other cell type. They responded to commissural stimulation with a burst response followed by suppression of firing. In contrast, the trilaminar neuron fired both early and late bursts. O-LM cells and the backprojection neurons on the other hand were inhibited by commissural stimulation and discharged only after the emergence of CA1 population spikes, indicating that they are innervated by local CA1 pyramidal cell collaterals but not by commissural fibers. Hyperpolarization of O-LM neurons evoked a prominent sag current (see also McBain, 1994), which was completely absent in the backprojection cells and very small in the other types. These preliminary observations suggest that a reliable relationship may exist between intrinsic properties, network behavior, and axonal targets of the different interneuronal types.

Kawaguchi et al. (1987) have shown previously that fast spiking neurons contain parvalbumin, and it was hypothesized that this calcium binding protein is causally related to the fast discharge of interneurons by reducing their accommodation and afterhyperpolarization (Celio, 1986). Although all neurons in this study were fast spiking, only basket cells were immunoreactive for parvalbumin, suggesting that parvalbumin is not related to the fast neuronal discharge.

Previous physiological and anatomical works have already indicated connectivity among interneurons. Both inhibitory and excitatory connections have been suggested to occur among interneurons (Misgeld and Frotscher, 1986; Lacaille et al., 1987; Michelson and Wong, 1991). A striking observation of the present study was the high probability of contacts among basket cells with approximately 60 parvalbumin-immunoreactive interneurons converging on a single basket cell. In line with the anatomical arrangement, inhibition of basket cell firing and the appearance of the early (putative $\mathrm{GABA}_{\mathrm{A}}$ ) and late (putative $\mathrm{GABA}_{\mathrm{B}}$ ) IPSPs occurred at similar stimulus intensities in both basket and pyramidal neurons. At low frequency stimulation basket cells did not fire more than three action potentials even at high stimulus intensities. However, the duration of postactivation suppression of cell discharge increased and the amplitude of both the early and especially the late IPSPs was augmented with stronger stimuli. These observations suggest that activation-dependent inhibition of pyramidal cells and basket cells cannot be explained by increased number of action potentials of the basket neurons. Rather, increased inhibition is likely due to recruitment of further basket cells and/or other interneurons terminating on the same target neurons. This explanation is in line with a previous suggestion that synaptically released GABA quickly saturates $\mathrm{GABA}_{\mathrm{A}}$ receptor channels (Faber et al., 1992); therefore, inhibition can be most efficiently augmented by synchronizing nearby synaptic terminals (Otis et al., 1994).

With stimulation frequencies faster than $1 \mathrm{~Hz}$, the number of action potentials in basket cells increased (Andersen et al., 1963; Buzsáki and Eidelberg, 1982; Sah et al., 1990; Lacaille, 1991; McBain, 1994). This may be due to presynaptic inhibition of GABA release or to the decreased effectiveness of the released GABA on basket cells as a result of increasing intracellular $\mathrm{Cl}^{-}$ concentration (Thompson and Gähwiler, 1989). Against this scenario, our observation that the trilaminar neuron had a late depolarizing potential even at low frequency stimulation suggests that the density of GABA receptors on trilaminar neurons is quite low. Overall, these physiological observations indicate that GABAergic innervation of interneurons may vary extensively.

Traditionally, inhibitory interneurons have been assumed to provide stability to the principal cell population by feed-back and feed-forward inhibition. Because of their expected spatial selectivity, interneurons were believed to have restricted axon collateral systems; hence, the frequently used term "local circuit interneurons." The widespread and interregional projection of interneurons, however, suggest new functions for interneurons. It has been hypothesized that ligand- or voltage-dependent oscillation of interneurons and their linking into cooperative ensemble patterns may be critical for theta, gamma, and ultrafast $(200 \mathrm{~Hz})$ population oscillations in the hippocampus (Fraser and 
MacVicar, 1991; Buzsaki et al., 1992; Bragin et al., 1995; Ylinen et al., 1995a). Indeed, networks of interneurons have been demonstrated to maintain population synchrony through $\mathrm{GABA}_{\mathrm{A}}$ synapses when fast and slow excitatory neurotransmission are blocked pharmacologically (Michelson and Wong, 1991; Whittington et al., 1995). These experiments provide support to the notion that principal cells and interneurons may form relatively separate circuitries and can function independently. Cooperative oscillations in interneuronal networks may serve to provide timing of the action potentials in spatially distant, slow discharging principal cells (Buzsáki and Chrobak, 1995).

\section{References}

Aika Y, Ren JQ, Kosaka K, Kosaka T (1994) Quantitative analysis of GABA-like immunoreactivity and parvalbumin containing neurons in the CA1 region of the rat hippocampus using a stereological method, the disector. Exp Brain Res 99:267-276.

Alger BE, Nicoll RA (1982) Feed-forward dendritic inhibition in rat hippocampal pyramidal cells studied in vitro. J Physiol (Lond) 328: 105-123.

Alonso A, Kohler C (1982) Evidence for separate projections of hippocampal pyramidal and non-pyramidal neurons to different parts of the septum in the rat brain. Neurosci Lett 31:209-214.

Amaral D, Witter M (1989) The three-dimensional organization of the hippocampal formation: a review of anatomical data. Neuroscience 31:571-591.

Andersen P, Eccles JC, Loyning Y (1963) Recurrent inhibition in the hippocampus with identification of the inhibitory cell and its synapse. Nature 198:540-542.

Baimbridgc KG, Miller JJ (1982) Immunocytochemical localization of calcium-binding protein in cerebellum, hippocampal formation and olfactory bulb of the rat. Brain Res 245:223-229.

Baude A, Nuesser Z, Roberts JDB, Mulvihill E, McIlhinney RAJ, Somogyi P (1993) The metebotropic glutamate receptor (mGluR1a) is concentrated at perisynaptic membrane membrane of neuronal subpopulations as detected by immunogold reaction. Neuron 11:771787

Bragin A, Jandó G, Nádasdy Z, Hetke J, Wise K. Buzsáki G (1995) Gamma $40-100 \mathrm{~Hz}$ ) oscillation in the hippocampus of the behaving rat. J Neurosci 15:47-60.

Buckmaster PS, Schwartzkroin PA (1995) Interneurons and inhibition in the dentate gyrus of the rat in vivo. J Neurosci 15:774-789.

Buhl E, Halasy K, Somogyi P (1994) Hippocampal unitary inhibitory postsynaptic potentials: diverse sources and number of synaptic release sites. Nature 368:823-828.

Buzsáki G (1984) Feed-forward inhibition in the hippocampal formation. Prog Neurobiol 22(1):31-153.

Buzsáki G, Eidelberg E (1982) Direct afferent excitation and long-term potentiation of hippocampal interneurons. J Neurophysiol 48:597607.

Buzsáki G, Chrobak JJ (1995) Temporal structure in spatially organized neuronal ensembles: a role for interneuron networks. Curr Opin Neurobiol 5:504-510.

Buzsáki G, Leung L, Vanderwolf CH (1983) Cellular bases of hippocampal EEG in the behaving rat. Brain Res Rev 6:139-171.

Buzsáki G, Horvath Z, Urioste R, Hetke J, Wise K (1992) High-frequency network oscillation in the hippocampus. Science 256:10251027.

Celio MR (1986) Parvalbumin in most $\gamma$-aminobutyric acid-containing neurons of the rat cerebral cortex. Science 231:995-997.

Faber DS, Young, WS, Legende P, Korn H (1992) Intrinsic quantal variability due to stochastic properties of receptor-transmitter interactions. Science 258:1494-1.

Finch DM, Nowlin NL, Babb TL (1983) Demonstration of axonal projection of neurons in the rat hippocampus and subiculum by intracellular injection of HRP. Brain Res 271:201-216.

Fraser DD, MacVicar BA (1991) Low-threshold transient calcium current in rat hippocampal lacunosum-moleculare interneurons: kinetics and modulation hy neurotransmitters. J Neurosci 11:2812-2820.

Freund TF, Gulyás AI, Acsady L, Gorcs T, Tóth K (1990) Serotonergic control of the hippocampus via local inhibitory interneurons. Proc Natl $\Lambda$ cad Sci USA 87:8501-8505.

Gulyás AI, Tóth K, Danos P, Freund TF (1991) Subpopulations of
GABAergic neurons containing parvalbumin, calbindin D28k, and cholecystokinin in the rat hippocampus. J Comp Neurol 312:371378.

Gulyás IA, Mietinen R, Jacobowitz MD, Freud TF (1992) Calretinin is present in non-pyramidal cells of the rat hippocampus-I. A new type of neuron specifically associated with the mossy fibre system. Neuroscience 1:1-27.

Gulyás AI, Miles R, Hajos N, Freund TF (1993a) Precision and variability in postsynaptic target selection of inhibitory cells in the hippocampal CA3 region. Eur J Neurosci 5:1729-1751.

Gulyás AI, Miles R, Sik A, Tóth K, Tamamaki N, Freund TF (1993b) Hippocampal pyramidal cells excite inhibitory neurons through a single rclcasc site. Nature 366:683-687.

Halasy K, Somogyi P (1993) Subdivision in the multiple GABAergic innervation of granule cells in the dentate gyrus of the rat hippocampus. Eur J Neurosci 5:411-429.

Han ZS, Buhl EH, Lörinczi Z, Somogyi P (1993) A high degree of spatial selectivity in the axonal and dendritic domains of physiologically identified local-circuit neurons in the dentate gyrus of the rat hippocampus. Eur J Neurosci 5:395-410.

Kawaguchi Y, Hama K (1987a) Two subtypes of non-pyramidal cells in rat hippocampal formation identified by intracellular recording and HRP injection. Brain Res 411:190-195.

Kawaguchi Y, Hama K (1987b) Fast-spiking non-pyramidal cells in the hippocampal CA3 region, dentate gyrus and subiculum of rats. Brain Res 425:351-355.

Kawaguchi Y, Katsumaru H, Kisaka T, Heizmann CW, Hama K (1987) Fast spiking cells in rat hippocampus (CAl region) contain the calcium-binding protein parvalbumin. Brain Res 416:369-374.

Kosaka T, Wu JY, Benoit R (1988) GABAergic neurons containing somatostatin-like immunoreactivity in the rat hippocampus and dentate gyrus. Exp Brain Res 71:388-398.

Kunkel DD, Lacaille J, Schwartzkroin PA (1988) Ultrastructure of stratum lacunosum-moleculare interneurons of hippocampal CAl region. Synapse 2:382-394.

Lacaille CJ (1991) Postsynaptic potentials mediated by excitatory and inhibitory amino acids in interneurons of stratum pyramidale of the CA1 region of rat hippocampal slices in vitro. J Neurophysiol 66: $1441-1454$

Lacaille CJ, Schwartzkroin AP (1988a) Stratum lacunosum-moleculare interneurons of hippocampal CAl region. I. Intracellular response characteristics, synaptic responses, and morphology. Neuroscience 8:1400-1410.

Lacaille CJ, Schwartzkroin AP (1988b) Stratum lacunosum-moleculare interneurons of hippocampal CA1 region. II. Intrasomatic and intradendritic recordings of local circuit synaptic interactions. Neuroscience 8:1411-1424.

Lacaille J, Williams S (1990) Membrane properties of interneurons in stratum oriens-alveus of the CA1 region of rat hippocampus in vitro. Neuroscience 36:349-359.

Lacaille JC, Mueller A, Kunkel DD, Schwartzkroin PA (1987) Local circuit interactions between oriens/alveus interneurons and CAl pyramidal cells in hippocampal slices: electrophysiology and morphology. J Neurosci 7:1979-1993.

Leung LS, Yim CY (1991) Intrinsic membrane potential oscillations in hippocampal neurons in vitro. Brain Res 553:261-274.

Li X-G, Somogyi P, Tepper JM, Buzsáki G (1992) Axonal and dendritic. arborization of an intracellularly labeled chandelier cell in the CA1 region of the rat hippocampus. Exp Brain Res 90:519-525.

Li X-G, Somogyi P, Ylinen A, Buzsáki G (1994) The hippocampal CA3 network: an in vivo intracellular labeling study. J Comp Neurol 339:181-208.

Llinás RR (1988) The intrinsic electrophysiological properties of mammalian neurons: insight into central nervous system function. Science 242::1654-1664.

Lopes da Silva FH, Witter MP, Boeijinga PH, Lohman AHM (1990) Anatomic organization and physiology of the limbic cortex. Physiol Rev 70:453-511.

McBain CJ (1994) Hippocampal inhibitory neuron activity in the elevated potassium model of epilepsy. J Neurophysiol 72:2653-2863.

McBain CJ, Dingledine R (1993) Heterogeneity of synaptic glutamate receptors on $\mathrm{CA} 3$ stratum radiatum interneurons of rat hippocampus. J Physiol (Lond) 462:373-392.

McBain CJ, DiChiara, TJ, Kauer JA (1994) Activation of metabotropic glutamate receptors differentially affects two classes of hippocampal 
interneurons and potentiates excitatory synaptic transmission. J Neurosci 14:4433-4445.

Michelson HB, Wong RKS (1991) Excitatory synaptic responses mediated by GABA receptors in the hippocampus. Science 253:14201423.

Miettinen, R, Gulyás AI, Baimbridge GK, Jacobowitz MD, Freund FT (1992) Calretinin is present in non-pyramidal cells of the rat hippocampus-II. Co-existence with other calcium binding proteins and GABA. Neuroscience 1:29-43.

Miles R, Poncer IC (1993) Metabotropic glutamate receptors mediate a post-tetanic excitation of hippocampal inhibitory neurones. J Physiol (Lond) 463:461-473.

Miles R, Tóth K, Gulyás $\Lambda \mathrm{I}$, Hájos N, Freund TF (1994) Distinct functional roles for somatic and dendritic inhibition in hippocampus. Soc Neurosci Abstr 20:710.

Misgeld U, Frotscher M (1986) Postsynaptic-GABAergic inhibition of non-pyramidal neurons in the guinea-pig hippocampus. Neuroscience 19:193-206.

Nicoll RA (1994) Cajal's rational psychology. Nature 368:808-809.

Otis TS, de Koninck Y, Mody I (1994) Lasting potentiation of inhibition is associated with an increased number of $\gamma$-aminobutiric acid type $A$ receptors activated during miniature inhibitory postsynaptic currents. Proc Natl Acad Sci USA 91:7698-7702.

Ramón y Cajal S (1911) Histologie du Systéme Nerveux de l'Homme et des Vertebrés. Paris: Maloine.

Ribak CE, Seress L, Peterson GM, Seroogy KB, Fallon JH, Schmued LC (1986) A GABAergic inhibitory component within the hippocampal commissural pathway. J Neurosci 6:3492-3.

Rogers JH (1989) Two calcium binding proteins mark many chick sensory neurons. Neuroscience 31:679-711.

Sah P, Hestrin S, Nicill RA (1990) Properties of excitatory postsynaptic currents recorded in vitro from rat hippocampal interneurons. J Physiol (Lond) 430:605-616.

Scharfman HE, Kunkel DD, Schwartzkroin PA (1990) Synaptic connections of dentate granule cells and hilar neurons: results of paired intracellular recordings and intracellular horseradish peroxidase injections. Neuroscience 37:693-707.

Schwartzkroin PA, Mathers LH (1978) Physiological and morphological identification of a nonpyramidal cell type. Brain Res 157:1-10.

Schwartzkroin PA, Kunkel DD (1985) Morphology of identified interneurons in the CA1 regions of guinea pig hippocampus. J Comp Neurol 232:205-218.

Seeburg PH (1993) The molecular biology of mammalian glutamate receptor channels. Trends Neurosci 16:369-365.

Sik A, Tamamaki N, Freund TF (1993) Complete axon arborization of a single CA3 pyramidal cell in the rat hippocampus, and its relationship with postsynaptic parvalbumin-containing interneurons. Eur J Neurosci 5:1719-1728.

Sik A, Ylinen A, Penttonen M, Buzsáki G (1994a) Inhibitory CA1CA3-hilar region feedback in the hippocampus. Science 265:17221724.

Sik A, Penttonen M, Ylinen A, Horvath Z, Buzsáki G (1994b) Intracellularly labeled hippocampal interneurons in vivo. Soc Neurosci Abstr 19:148.15.

Sloviter, RS (1989) Calcium-binding protein (Calbindin-D28k) and parvalbumin immunocytochemistry: localization in the rat hippocam- pus with specific reference to the selective vulnerability of hippocampal neurons to seizure activity. J Comp Neurol 280:183-196.

Sloviter RS, Nilaver G (1987) Immunocytochemical localization of GABA-, cholecystokinin-, vasoactive intestinal polypeptide-, and somatostatin-like immunoreactivity in the area dentata and hippocampus of the rat. J Comp Neurol 256:42-60.

Soltész I, Deschenes M (1993) Low- and high-frequency membrane potential oscillations during theta activity in $\mathrm{CA} 1$ and $\mathrm{CA} 3$ pyramidal neurons of the rat hippocampus under ketamine-xylazine anesthesia. J Neurophysiol 70:97-116.

Somogyi P, Nunzi MG, Gorio A, Smith AD (1983) A new type of specific interneuron in the monkey hippocampus forming synapses exclusively with the axon initial segments of pyramidal cells. Brain Res 137-142.

Somogyi P, Hodgson AJ, Smith AD, Nunzi MG, Gorio A, Wu JY (1984) Different populations of GABAergic neurons in the visula cortex and hippocampus of the cat containing somatostatin- or cholecystokinin-immunoreactive material. J Neurosci 4:2590-2603.

Strublc RG, Desmond NL, Levy WB (1978) Anatomical evidence of interlamellar inhibition in the fascia dentata. Brain Res 152:580-585.

Tamamaki N, Nojyo Y (1990) Disposition of the slab-like modules formed by axon branches originating from single CA1 pyramidal neurons in the rat hippocampus. J Comp Neurol 291:509-519.

Tamamaki N, Nojyo Y (1991) Crossing fiber arrays in the rat hippocampus as demonstrated by three-dimensional reconstruction. J Comp Neurol 303:435-442.

Tamamaki N, Nojyo Y (1995) Preservation of reciprocal connections between the subiculum, field CAl and the entorhinal cortex in the rats. J Comp Neurol, in press.

Tamamaki, N, Abe K, Nojyo Y (1988) Three-dimensional analysis of the whole axonal arbors originating from single CA2 pyramidal neurons in the rat hippocampus with the aid of a computer graphic technique. Brain Res 452:255-272.

Thompson SM, Gähwiler BH (1989) Activity-dependent disinhibition I. Repetitive stimulation reduces IPSP driving force and conductance in the hippocampus in vitro. J Neurophysiol 61:501-511.

Tóth K, Freund TF (1992) Calbindin D28k-containing nonpyramidal cells in the rat hippocampus: their immunoreactivity for GABA and projection to the medial septum. Neuroscience 49:793-805.

Tóth K, Borhegyi Z, Freund TF (1993) Postsynaptic targets of GA BAergic hippocampal neurons in the medial septum-diagonal band of Broca complex. J Neurosci 13:3712-3724.

Traub RD, Miles R (1991) Neuronal networks of the hippocampus. Cambridge: Cambridge UP.

Traub RD, Jefferys JGR, Miles R, Whittington MA, 'Toth K (1994) A branching dendritic model of a rodent $\mathrm{CA} 3$ pyramidal neurone. $\mathrm{J}$ Physiol (Lond) 481:79-95.

Whittington MA, Traub RD, Jefferys JGR (1995) Metabotropic receptor activation drives synchronized $40 \mathrm{~Hz}$ oscillations in networks of inhibitory interneurons. Nature 373:612-615.

Ylinen A, Bragin A, Nadasdy Z, Jando G, Szabo I, Sik A, Buzsáki G (1995a) Sharp wave associated high frequency oscillation $(200 \mathrm{~Hz})$ in the intact hippocampus: network and intracellular mechanisms. J Neurosci 15:30-46.

Ylinen A, Soltész I, Bragin A, Penttonen M, Sik A, Buzsáki G (1995b) Intracellular correlates of hippocampal theta rhythm in identified pyramidal cells, granule cells and basket cells. Hippocampus 5:78-90, 1995. 